Article

\title{
A Sustainable Historic Waterfront Revitalization Decision Support Tool for Attracting Tourists
}

\author{
Ali Keyvanfar 1,2,3,4 (iD, Arezou Shafaghat 2,3,4,*, Sapura Mohamad ${ }^{3}$, \\ Mu'azu Mohammed Abdullahi ${ }^{5}$, Hamidah Ahmad ${ }^{3}$, Nurul Hidayah Mohd Derus ${ }^{3}$ and \\ Majid Khorami ${ }^{1}$ \\ 1 Facultad de Arquitectura y Urbanismo, Universidad Tecnológica Equinoccial, Calle Rumipamba s/n y \\ Bourgeois, Quito 170508, Ecuador; akeyvanfar@utm.my (A.K.); Majid.khorami@ute.edu.ec (M.K.) \\ 2 MIT-UTM MSCP Program, Institute Sultan Iskandar, Universiti Teknologi Malaysia, Skudai 81310, Malaysia \\ 3 Department of Landscape Architecture, Faculty of Built Environment, Universiti Teknologi Malaysia, \\ Skudai 81310, Malaysia; b-sapura@utm.my (S.M.); b-hamidah@utm.my (H.A.); \\ nurulhidayahbintimohdderus@gmail.com (N.H.M.D.) \\ 4 The School of Architecture and Environmental Design, Iran University of Science and Technology (IUST), \\ Narmak Street, Tehran 1684613114, Iran \\ 5 Civil Engineering Department, Jubail University College, Royal Commission of Jubail and Yanbu, \\ Jubail 31961, Saudi Arabia; mmuazuabdulahi@gmail.com \\ * Correspondence: arezou@utm.my; Tel.: +1(858)-264-7085
}

Received: 8 November 2017; Accepted: 17 January 2018; Published: 23 January 2018

\begin{abstract}
Waterfront revitalization would be an effective strategy to preserve heritages, conserve the contaminated or abandoned site and inspire the identity and authenticity. However, there is no decision support tool to quantify and evaluate the sustainability accreditation of waterfronts in tourism attraction. This research aimed to identify the most potential waterfront typology in tourism attraction and develop the waterfront sustainable revitalization (SWR) index assessment model. The SWR index can assist policy makers and urban developers to analyze the heritage waterfronts using Analytical Hierarchy Process (AHP) method. The research found out the historic waterfront has the highest potential in tourism attraction among other typologies. And, pollution moderator is mostly important sub-criterion in tourism absorption $\left(\mathrm{W}_{\mathrm{C} 2.2}=0.1294\right)$; followed by Identity $\left(\mathrm{W}_{\mathrm{C} 1.2}=0.1272\right)$ and Safety and well-being $\left(\mathrm{W}_{\mathrm{C} 1.3}=0.1043\right)$. The SWR index can be applied in any waterfronts in heritage cities around the world, while this research implemented it as a case study in Bandar Maharani, Muar, Malaysia. It resulted Bandar Maharani was ranked as grade C; means, usable waterfront to which extent environmental, social and physical revitalization are needed. The SWR index can be coupled with other decision-making methods in future, to reduce its inconsistencies and increasing accuracy.
\end{abstract}

Keywords: waterfront; revitalization; tourism attraction; sustainable development; Analytical Hierarchy Process (AHP); decision support tool

\section{Introduction}

Waterfronts are the most attractive water features for human settlement. Waterfront is defined as the zone of interaction between urban development and the water where the needs of the city and its inhabitants blend together [1]. As there are global changes on built environment, several social, economic and environmental problems were occurred in waterfronts development [2-6]. On the social aspect, the urban rapid development has destroyed many cultural and old buildings or places in waterfronts $[7,8]$. Hence, people and particularly tourists, have lost their interaction with old buildings and might lose their connection with local culture and heritage. On the environmental 
aspect, the waterfront loses its identity and legacy values and become less attractive for both tourist and local people [8,9]. In this regard, UNESCO (United Nations Educational, Scientific and Cultural Organization) indicated two approaches to tourism attraction; (i) Natural and (ii) Cultural [10]. The natural type designates outstanding physical, biological and geological features, habitats of threatened plants or animal species and areas of value on scientific or aesthetic grounds or from a conservation perspective and the cultural type designates a monument, group of buildings or site of historical, aesthetic, archaeological, scientific, ethnological or anthropological values $[10,11]$. On the economic aspect, rapid development has worsened the economic situation and hence, the old commercial areas become abandoned where no commercial activities occur [12,13]. Hence, waterfront's social and community, physical and environmental and economic situations need a sustainable revitalization strategy [14]. Indeed, sustainable revitalization strategies can help the waterfronts to re-energize the communities and public spaces $[7,8,13,15,16]$. In particular, waterfront revitalization can play a vital role in tourism attraction [17-20]. Indeed, tourism attraction can help to create a strong connection between the tourism spots and values of the places. The main reasons for focusing on tourism attraction in waterfront revitalization are:

I. Growth of the abandonment housing areas;

II. The loss of cultural and historical values due to the destruction and rebuilding of old buildings;

III. Economic declination due to the new and modern marketing in new developed areas;

IV. Unhealthy social lifestyle and less interaction with the environment.

The revitalization strategy can be applied to diverse types of waterfronts. The previous researchers (included, Refs. [1,21-23]) have classified the waterfront types based on functionalities. Vallega [23] has categorized the waterfront based on waterland uses as; Ecosystem enjoyment, Fishing, Tourism, Recreation, Entertainment, Congresses, Media, Transport and navigation, Trade and finance, Research areas, Education and training and Cultural heritage. Nonetheless, Breen and Rigby [1] have established comprehensive waterfront typologies that are adaptable for policy-making studies. Breen and Rigby [1] states waterfronts can be categorized into six (6) typologies; namely, commercial, educational, environmental, historic, recreational, residential and working and transportation waterfronts. The commercial waterfront encourages public enjoyment of the waterfront for work, shopping or recreation [10,11,24]. From major aquariums to emotionally charged memorials, waterfront cultural and educational sites are among the most engaging features of modern cities $[9,25]$. Such waterfront provides beautiful settings for religious architecture, memorials, public art and grand cultural institutions for generations. Instead of condemning old waterfront structures to be non-usable (i.e., decay and ultimate abandonment), the historic waterfront cities are working towards the preservation and adaptive reuse of historic buildings and precincts, favouring a restorative approach that in the end makes for a richer community $[25,26]$. The recreational waterfront provides an enjoyable area for spending leisure time, fishing, swimming or quiet contemplation [27]. The residential waterfront provides the waterside for a living. Although old residential waterfronts were very attractive, developers today create artificial lakes and ponds in the residential surrounding where attraction injections are significantly needed for the environment [28,29]. Meanwhile, the working and transportation waterfronts are associated with the working port and industrial and transportation facilities [8,30]. For revitalization purpose, each type of waterfront has undoubtedly its individual significant potential for tourism attraction but the question is which type of waterfront has the most potential?

The waterfront revitalization needs to be evaluated and assessed. The researchers have assessed the waterfront revitalization using the multi-criteria decision-making (MCDM) methods; however, there are very few studies in the literature. These studies have followed different approaches and decision-making analysis methods. Sairinen and Kumpulainen [7] have developed an index system to assess the social impact of waterfront urban plans from four perspectives; access and activities, resources and identity, social status and waterfront experience. Da and $\mathrm{Xu}$ [8] state "there still 
lacks assessment systems on implementation effects of urban waterfront redevelopment projects". Cuesta et al. [31] state that SWOT (Strengths, Weaknesses, Opportunities and Threats) method is such an analytical decision-making method "for identifying the properties and potential of an urban area". Doratli et al. [25] have applied the SWOT method for analyzing revitalization strategies in historic urban quarters. The SWOT method has a descriptive dimension that criticizes the backward and forward linkages of urban revitalization plans and proposals. Doratli et al. [25] has applied the SWOT method for intensities of development pressures, place assets and obsolescence in historic urban revitalization. Doratli et al. [25] express also however SWOT has relatively low level of sophistication and reliability to support the decision-making process. Romero et al. [4] have applied the artificial neural network (ANN) method to evaluate the landscape and soundscape of waterfront particularly sonic and visual parameters. ANN is a computational model estimates unidentified functions within an interconnected neurons system [32]. Romero et al. [4] express that ANN enables the waterfront designers to understand a good approximation of values in soundscape perception analysis. Da and $\mathrm{Xu}[8]$ have established an assessment index for evaluating urban waterfront connectivity using hesitant fuzzy linguistic method. They particularly applied this method for landscape restoration in urban exploitation projects from social, ecological and physical and contextual impact perspectives. The hesitant fuzzy linguistic method aids the experts to make a decision through linguistic evaluation values. The hesitant fuzzy method scores functionally the evaluation results and then select the best alternative. Da and $\mathrm{Xu}[8]$ state the best alternative indicates the structural and functional enhancement on the urban waterfront connectivity values. Yamashita [33] has applied photo-projective method (PPM) to explore water landscapes' visual values and qualities. Cai and $\mathrm{Hu}$ [34] have conformed the PPM method for the evaluation of the functional characteristics of urban rivers, focusing on social indicators. Lifang et al. [9] states that however Analytic Hierarchy Process (AHP) can be applied to "to the establishment of an evaluation model for landscape design of urban rivers". Lifang et al. [9] express that "AHP improves the accuracy of evaluation of the rationality of the landscape design of urban rivers". In wetland planning studies, Chatterjee et al. [35] have investigated causes of wetland degradation using Fuzzy ANP (Analytical Network process) and Zhang et al. [36] have applied AHP (Analytical Hierarchy process) for evaluation of wetland ecosystem stability. Li-fang et al. (2012) express that "AHP is one of the most thriving methods in the comprehensive evaluation or resource evaluation of the urban wetland parks, forest parks and wetland parks".

Table 1 presents the critical comparison of MCDM methods have been applied in waterfront revitalization assessment, as well as, the MCDM methods have potentials to be applied. According to Table 1, among MCDM methods, AHP method has been mostly referred; means, AHP can significantly upgrade the previous waterfront revitalization assessment studies, in particular, it can be employed for developing a waterfront revitalization decision support tool (as the aim of this study). Indeed, AHP (developed by Saaty [37]) is the most appropriate method for evaluating problems with uncertain indicators [35]. Velasquez and Hester [38] state that AHP method is such an easy-to-use and scalable method which its "hierarchy structure can easily adjust to fit many sized problems; not data intensive". AHP can be applied in "performance-type problems, resource management, corporate policy and strategy, public policy, political strategy and planning" [38]. Also, it can be used for both individual and group decision-making scenarios [39]. The AHP is a multi-criteria decision-making method, which considers both qualitative and quantitative criteria in a single metric [40]. It is a plausible method that covers the logical and scientific approaches in a multi criteria decision-making [41,42]. According to Table 1, AHP is applicable for all types of decision; routine, adaptive and innovative decision. Means, AHP method is applicable when the problems are common and relatively well-defined, when problems are unusual and partially understood and when problems are unclear and creative solutions are needed. AHP method also is applicable to different levels of decision; strategic, administrative and operational. Hence, it is an established method for crucial and long-term decisions for day-to-day problems made by the top-managers, middle-managers and first-line managers which improves functioning. 
Table 1. A critical comparison of multi-criteria decision-making (MCDM) methods have been applied / have potentials for waterfront revitalization assessment.

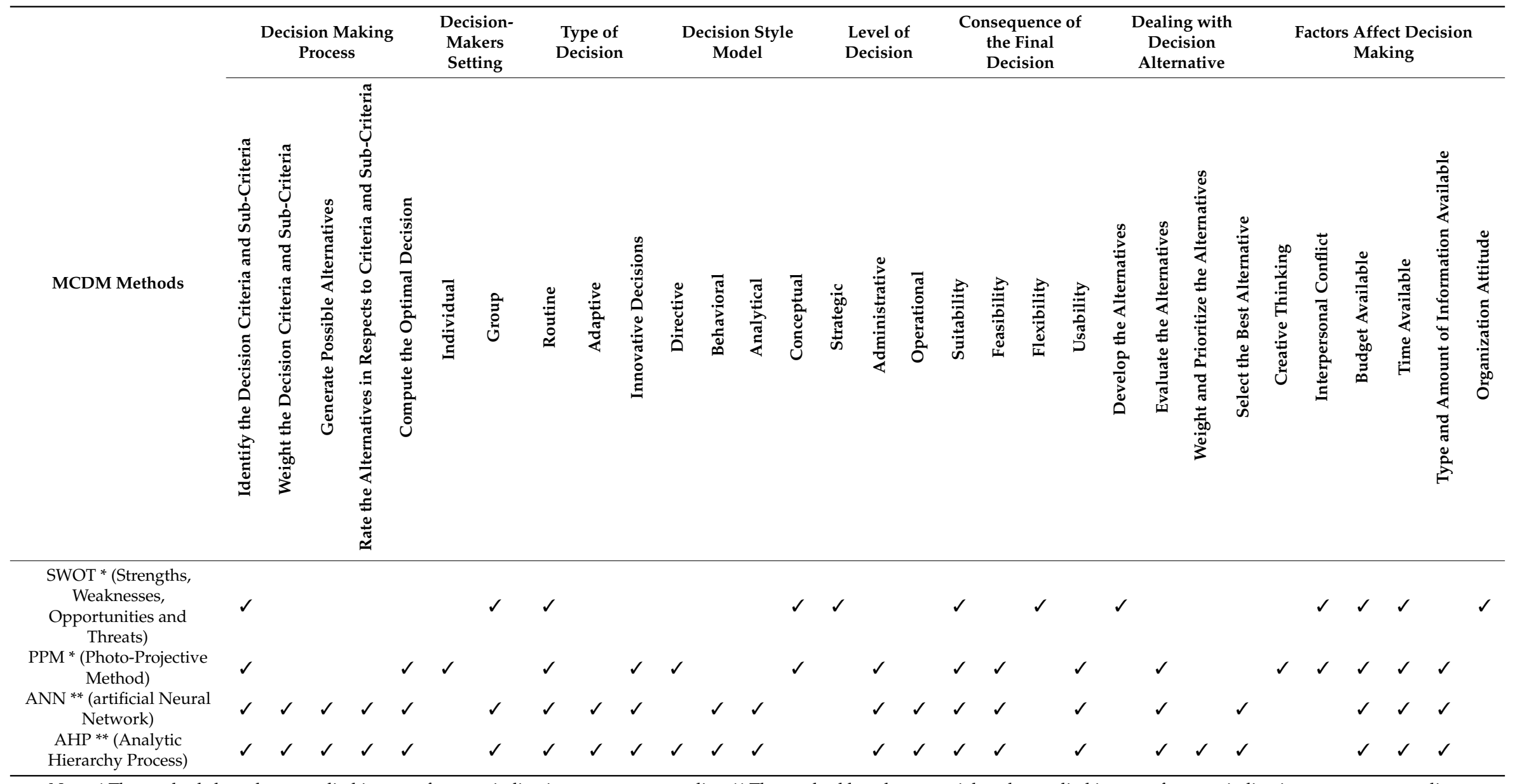

\footnotetext{
Note: * The methods have been applied in waterfront revitalization assessment studies, ${ }^{* *}$ The method has the potentials to be applied in waterfront revitalization assessment studies.
} 
According to above-mentioned issues, there is no waterfront revitalization decision support tool to evaluate and quantify the capabilities for attracting tourists using AHP method. In this regard, the current research aimed to develop such a decision support tool by achieving two objectives; to identify the waterfront type and the features which have the most potential to attract tourists; and to develop and validate the sustainable waterfront revitalization (SWR) index using AHP method. Applying this tool enables policy makers and urban and landscape designers and planners to evaluate and benchmark the revitalized waterfronts on functionalities and capabilities for attracting tourism.

\section{Materials and Method}

\subsection{Waterfront Typologies}

All six (6) type of waterfronts mentioned in the introduction have been involved in the AHP analysis. The six types of waterfront were considered as the six alternatives (i.e., Alt.) of decision-making in this study; as. Alt. 1. The Commercial Waterfront, Alt. 2. The Educational and Environmental Waterfront, Alt. 3. The Recreational Waterfront, Alt. 4. The Historic Waterfront, Alt. 5. The Residential Waterfront and Alt. 6. The working and Transportation Waterfront. AHP will analyze and indicate which type of waterfront has the most potential for attracting tourist.

\subsection{Waterfront Revitalization Features for Tourist Attraction}

Developing the waterfront sustainable revitalization (SWR) decision support tool needs the comprehensive list of waterfront revitalization features for tourism attraction. The features have been identified through a deep review on functionalities of different types of waterfront and through a systematic literature review using specific combination of keywords; included, waterfront revitalization, waterfront assessment, tourism attraction and landscape design and planning approaches in the available references. A systematic review was conducted in this study, as it is a replicable, scientific and transparent method of literature review [43], which can minimize bias of features selection. Both cited and referenced articles were extracted from the available databases of ScienceDirect, Google Scholar, Scopus, Taylor and Francis, Emerald, and Sage. Indeed, the most of articles reviewed were retrieved from high ranked journals; included, Tourism Management, Advances in Science and Technology of Water Resources, Habitat International, Sustainability, Urban Policy and Research, Cities, in addition to government reports, inventories and conference papers. The following presents the waterfront revitalization features clustered based on three bottom-lines of sustainability (i.e., Criteria: social, environmental and economic). All following fifteen (15) features have been involved in the AHP analysis (as sub-criteria). AHP will indicate the normalized weightage of each sub-criterion in tourist attraction. The normalized weightages will be transferred to the SWR index.

\section{C1. Social and Cultural Revitalization}

C1.1. Identity: The local culture and background need to be considered and enhanced as the distinctive identity of the waterfront town that represents the image of the waterfront to visitors [44]. Besides, the vitality of waterfront landscape will be enhanced [45].

C1.2. Authenticity: It is a respect to the cultural contexts for the heritage properties and communities that care for them. For tourism, a more flexible term can be used as they find ways to tell the community's story of a place in ways that are meaningful, truthful and provide a strong experience for visitors.

C1.3. Safety and well-being: Waterfront revitalization provides better safety and access to downtown areas which can ameliorate economic conditions [46].

C1.4. The sense of place: The cities can create a distinct sense of place through preservation of heritage values and historical buildings to attract visitors and investors $[47,48]$. 
C1.5. Building gathering areas: The gathering area is defined as a place where people and wildlife are able to congregate and gather $[40,49,50]$. According to the Waterfront Design Guideline, building and other site functions should be planned to create outdoor gathering areas (i.e., such as amphitheaters, restaurant, plaza, square and promenade) and performance area and the development of spaces connected with other activities is encouraged.

C1.6. The sense of enjoyment: An active waterfront site with diversity in activities and functions can create an inclusive enjoyable environment for a diverse range of people and ages.

C2. Physical and Environment Revitalization

C2.1. Habitat and Natural preservation: Waterfront zone includes highly productive and biologically diverse ecosystems that offer crucial nursery habitats for many marine species. The green zone along the water body has to be reserved as habitat for flora and fauna for any development close to waterfront areas. Maintaining river reserve as a buffer zone is important to control environmental problem such as soil erosion. Also, waterfront zone features such as mangrove forests serve as a critical natural defense against natural hazards (i.e., flooding, erosion and storms).

C2.2. Pollution moderator: Water ecosystems may act to reduce the impacts of pollution originating from land, for example, wetlands absorbing excess nutrient sediments and human waste.

C2.3. Accessibility: According to Nelson [51], the area should give a clear direction for people to walk and enjoy the waterfront and give a sense of welcoming to attract visitors to visit the waterfront.

C2.4. Dynamic site design: The riverfront should be planned and designed with flexible elements that will allow it to adapt to the changes of a new era of water body morphology to support the long-term evolution and success of waterfront development [52]. Incompatible land uses such as cargo handling (which would obstruct the continuity of the harbor front promenade) and major infrastructure projects such as roads (which create a visual and physical barrier to the open water) should be avoided. The layout arrangement for waterfront space should be clear and legible for users to visit the waterfront.

C2.5. Building walkable outdoor environment: A streetscape development in creating a walkable outdoor shopping environment is essential to enhance the attractive and enjoyable environment and simultaneously, improves the economic development opportunities [52-55]. As described by Lopez-Bonilla et al. [15], a streetscape with a comfortable outdoor pedestrian environment in the commercial area can help in attracting visitors and enhance the economic development of that particular area as well.

C2.6. Providing facilities and amenities: They are needed in recreational areas such as a park, gazebo and sitting benches, as well as other related areas where they can give an activity along the waterfront.

C3. Economic and Functional Revitalization

C3.1. Mixed-use development: A mixed-use development of retail, office and housing is deliberated to create an outdoor shopping and commercial environment [53].

C3.2. Diversification: It helps communities that are possibly dependent on the industry [56].

C3.3. Employment opportunities: Tourism increases employment opportunities. Additional jobs ranging from low-wage entry-level to high-paying professional positions in management and technical fields generate income to the waterfront town area.

\subsection{Analytical Hierarchy Process (AHP)}

The current research has developed the waterfront sustainable revitalization (SWR) decision support tool by employing the AHP method. The AHP method applies a series of pairwise comparison 
of the waterfront revitalization features to determine weightage of each, as well as, their co-relationship. The research methodology of this study has engaged two phases. Phase one is to indicate the weightage of each feature (i.e., sub-criterion) on indication of the most potential waterfront typology in tourist attraction. Phase two is to develop the SWR assessment index and validate it through a case study.

In this study, AHP method has been conducted following this procedure:

Step 1: Hierarchy decomposition: The decision-making problem has been converted into a hierarchy.

Step 2: Pairwise comparison: The features have been pair-wisely compared to each other. The research has $K$ respondent experts with $n$ criteria, the results form for each expert in direct relation of $n \times n$ matrix which donated as $x_{i j}^{k}$, where $i j$ is the influential level of criterion $i$ to the criterion $j$. The research has conducted an expert input study to analyze the weightage of the features (i.e., sub-criteria) doing pairwise comparison. The research conducted an expert input survey where the invited experts have been asked to value pairwise comparison to all hierarchy elements (including features and alternatives). The pairwise comparison questionnaire has been designed based on nine-point scaling (from equal importance to extreme importance). The experts determined the valid importance of each series of comparison between criteria.

Step 3: Supermatrix development: The output of pair-wise comparisons has constructed a supermatrix. According to AHP method, the structure of the supermatrix consists a number $(M)$ of alternatives (i.e., waterfront typologies) and a number $(N)$ of decision criteria (i.e., waterfront revitalization features). The features have been compared with each other and the alternatives have also been evaluated for each feature, in order to understand the importance (i.e., weightage) of all hierarchy elements. Let $C_{i j}(I=1$ and $N=1,2,3, \ldots, N)$ denote the performance value of the alternatives (i.e., $A_{i}$; waterfront typologies) in terms of the $j$ th criterion (i.e., $C_{j}$ ). Also, denote $W_{j}$ as the weight of the criterion $\left(C_{j}\right)$. Then, the core of the typical AHP decision-making hierarchy can be represented by the decision-making supermatrix (Table 2). The supermatrix has been analyzed applying the AHP Equation (1);

$$
A_{A H P}^{i}=\sum_{j=1}^{N} a_{i j} W_{j} \text { for } I=1,2,3, \ldots, M
$$

Table 2. AHP decision-making supermatrix of waterfront revitalization.

\begin{tabular}{ccccccc}
\hline & \multicolumn{7}{c}{ Criterion } \\
\cline { 2 - 7 } Alternatives & & C1 & C2 & C3 & $\ldots$ & C15 \\
& Alt. & W1 & W2 & W3 & $\ldots$ & W15 \\
& A1 & C11 & C12 & C13 & $\ldots$ & A1,15 \\
& A2 & C21 & C22 & C23 & $\ldots$ & A2,15 \\
& A3 & C31 & C32 & C33 & $\ldots$ & A3,15 \\
& $\ldots$ & $\ldots$ & $\ldots$ & $\ldots$ & $\ldots$ & $\ldots$ \\
& A6 & C61 & C62 & C63 & $\ldots$ & A6,15 \\
\hline
\end{tabular}

Step 4: Normalization: This step was to normalize the pair-wise comparison supermatrix by totaling the numbers in each column. Each entry in the column was then divided by the column sum to yield its normalized score. After pairwise comparisons by experts, the normalization of weightages has been conducted by making equal to 1 , and, the sum of entries on each column of matrix (i.e., each entry $\overline{C_{j n}}$ of the matrix of normalization) was calculated by following Equation (2);

$$
\overline{C_{j n}}=\frac{C_{j n}}{\sum_{i=1}^{m} C_{i n}}
$$


Finally, the criterion's weight vector " $w$ " (that is an m-dimensional column vector) was built by averaging the entries on the row of normalization matrix applying the following Equation (3);

$$
W_{j}=\frac{\sum_{l=1}^{m} \bar{C}_{j l}}{m}
$$

where $C_{i j}$ : denotes the entry in the row and $j$ th column of normalized matrix; $v_{i}$ : denotes the $i$ th element of $v$.

Step 5: Consistency analysis: The purpose of consistency was to make sure that the original preference ratings were consistent. In AHP pairwise comparison judgment matrix is considered adequately consistent if the corresponding consistency ratio (CR) is less than 10\% [37]. The CR coefficient is calculated by dividing CI to RI (see Table 3). The CR is a normalized value since it is divided by an arithmetic mean of random matrix consistency indexes (RI) [40].

$$
C R=\frac{C I}{R I}=\frac{\left(\lambda_{\max }-n\right) /(n-1)}{R I}
$$

where $\lambda_{\max }$ maximum eigenvalue; $n$, rating value (1 to 9).

Table 3. Random Inconsistency (RI) indices for n nodes (Adopted from Alonso and Lamata [57]).

\begin{tabular}{cccccccccccccccc}
\hline$n$ & 1 & 2 & 3 & 4 & 5 & 6 & 7 & 8 & 9 & 10 & 11 & 12 & 13 & 14 & 15 \\
\hline $\mathbf{R C I}$ & 0 & 0 & 0.58 & 0.90 & 1.12 & 1.24 & 1.32 & 1.41 & 1.45 & 1.48 & 1.51 & 1.53 & 1.55 & 1.56 & 1.58 \\
\hline
\end{tabular}

\section{Analysis}

Referring to the results if first phase, the research has focused on the Historic Waterfront; so, the study is developing the Historic Waterfront Sustainable Revitalization index model. In this section, the procedure of developing the Historic SWR model is presented. The Historic SWR model applies AHP method to formulate the indexing. The AHP's steps are presenting as follow.

Step 1 analysis: The ultimate hierarchical structure of waterfront revitalization for tourist attraction is presented in Figure 1. Referring to AHP structure, the top layer is the goal of decision-making, the middle layer involves the decision-making criteria and the bottom layer includes the alternatives.

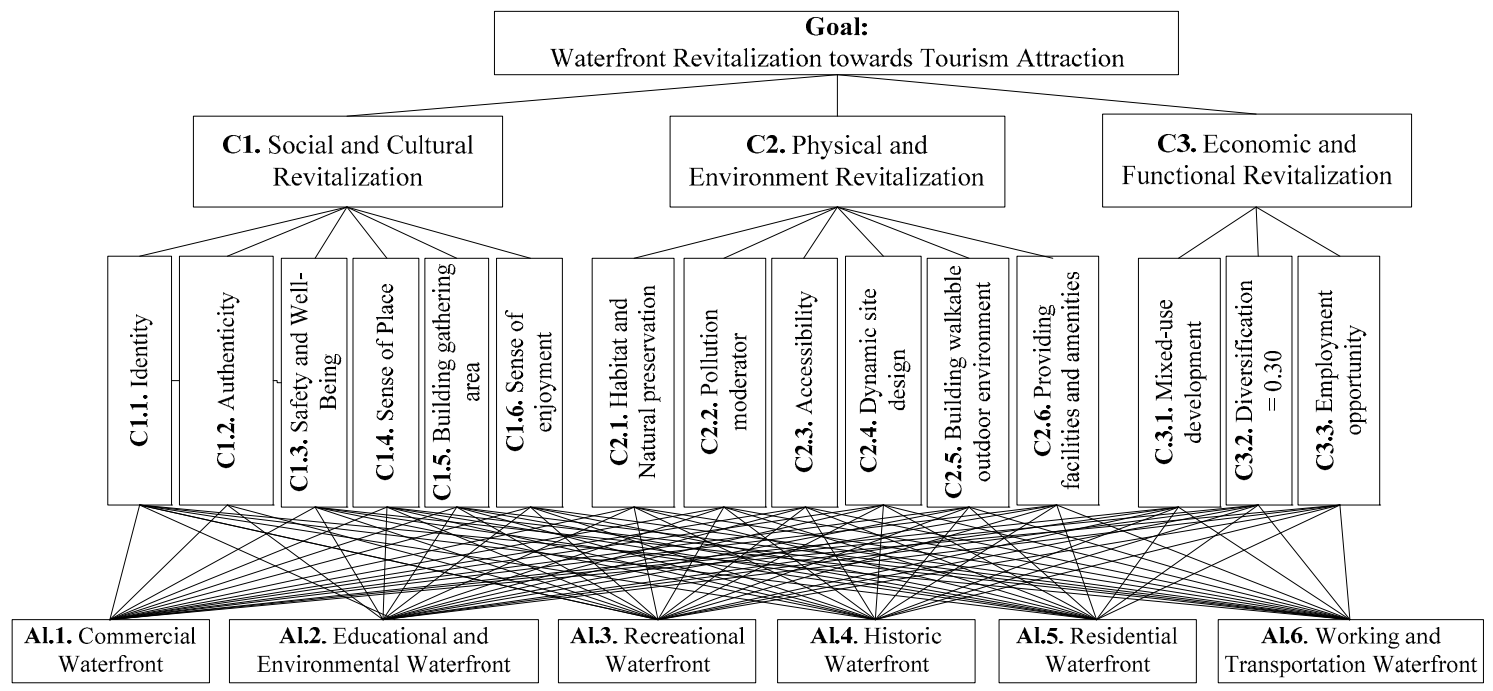

Figure 1. AHP hierarchical structure of waterfront revitalization for tourist attraction. 
Step 2 analysis: For development of the Historic SWR index assessment model, the research has evaluated the waterfront revitalization features on indication of the most potential waterfront typology applying the AHP method. The research has applied purposive sampling method for experts data inputs, which is align with the exploratory nature of the research. The purposive sampling is employed when random sampling is not appropriate due to lack of access to entire group and only a limited number of relevant cases are available [58]. The aim of purposive sampling in this study is to select rich-in-information experts to get deep information, so, it is not necessary to take huge samples when smaller ones produce the same results [59]. The number of participants selected for purposive sampling is often small [60]. For this research, five experts have been invited who each had around ten years' experience in urban policy making, particularly in waterfront landscaping, conservation and revitalization. On pairwise comparison, the experts have rated each criterion based on AHP's 9-point rating scale (1 (Equal important) to 9 (Extremely important)) using the questionnaire. For example, the survey questionnaire asked the experts: in waterfront revitalization for tourism attraction purpose, how much 'identity' is important compared to "safety"?

Step 3 analysis: The AHP's supermatrix was conducted based on hierarchy structure of criteria with the aid of an outsourced software (developed by SCB Associates Ltd., Stoneleigh, UK). This is professional and user-friendly stand-alone software for constructing AHP decision models. Based on AHP methodology, first, a pairwise comparison matrix was conducted on revitalization criteria (Table 4); next, the pairwise comparisons were performed on all waterfront typologies in respect to each criterion (see Appendix A).

Step 4 analysis: Table 4 shows the pairwise comparison of each criterion has been appointed during decision-making process. Calling Equation (2), the normalized weightage for each criterion was then calculated. Normalized weightage show the importance value of the criterion. Normalized weightage of each criterion was yielded by dividing sum of each criterion entries in the row (i.e., $\overline{C_{j n}}$ ) to its column sum. The normalization of weightages have been conducted by making sum of normalized weightages of criteria equal to 1 . According to Table 4 Pollution moderator is the most important criterion $\left(\mathrm{W}_{\mathrm{C} 2.2}=0.1294\right)$ in attracting tourism, which was followed by Identity $\left(\mathrm{W}_{\mathrm{C} 1.2}=0.1272\right)$, Safety and well-being $\left(\mathrm{W}_{\mathrm{C} 1.3}=0.1043\right)$. In contrast, the Building gathering areas and Sense of enjoyment have received the least importance rate among all criteria, $W_{C 1.5}=0.0241$ and $W_{C 1.6}=0.0261$, respectively.

The research has conducted the same AHP pair-wise comparison procedure to identify the most contributor waterfront typology attracts tourism (see Appendix A). AHP analysis on six waterfront typologies (i.e., Alternatives) which have been pair-wisely compared across fifteen (15) sub-criterion. Table 5 has used the normalized weightage analysis results reported in the Appendix A. According to Table 5 Historic Waterfront has received the highest weightage $\left(\mathrm{W}_{\mathrm{Alt} .4}=0.2410\right)$. Other typologies although has less contribution in attracting tourists; resulted, Educational and Environmental Waterfront $\left(\mathrm{W}_{\text {Alt.2 }}=0.2107\right)$, Recreational Waterfront $\left(\mathrm{W}_{\text {Alt.3 }}=0.1962\right)$ and Working and Transportation Waterfront $\left(\mathrm{W}_{\text {Alt. } 6}=0.1434\right)$. The Residential waterfront (i.e., Alt. 5) has received the lowest weightage $(\mathrm{W}=0.0813)$. Figure 2 illustrates the cumulative weightage of each waterfront typologies in tourism attraction. Although the Historic Waterfront has the highest cumulative weightages, the working and Transportation Waterfront typology (i.e., Alternative 6) plays the better role in terms of Pollution moderator. Furthermore, in terms of Safety and Well-being, the Educational and Environmental Waterfront typology is more significant than Historic Waterfront.

Step 5 analysis: The Consistency Index $(\mathrm{CI})$ has been calculated $(\mathrm{CI}=0.139)$. Referring to Table 3, RI was 1.58; then CR coefficient was calculated as CI/RI $=0.087(<10 \%)$. Referring to Saaty [37] suggestion, the ratio was less than $10 \%(<0.10)$, thus, the decision-making result was consistent enough. 
Table 4. Normalized supermatrix of waterfront revitalization sub-criteria.

\begin{tabular}{|c|c|c|c|c|c|c|c|c|c|c|c|c|c|c|c|c|}
\hline & C1.1. & C1.2. & C1.3. & C1.4. & C1.5. & C1.6 & C2.1. & $\mathrm{C} 2.2$. & C2.3. & C2.4. & $\mathrm{C} 2.5$. & C2.6. & C3.1. & C3.2. & C3.3. & Normalized Weightage \\
\hline C1.1. & 0.0971 & 0.1838 & 0.5302 & 0.1098 & 0.0445 & 0.0689 & 0.0558 & 0.0219 & 0.1903 & 0.0494 & 0.0708 & 0.1846 & 0.1237 & 0.1115 & 0.0663 & 0.1272 \\
\hline C1.2. & 0.0121 & 0.0230 & 0.0177 & 0.0110 & 0.0296 & 0.0344 & 0.1394 & 0.2189 & 0.0952 & 0.0124 & 0.0708 & 0.0527 & 0.0041 & 0.0056 & 0.0041 & 0.0487 \\
\hline C1.3. & 0.0162 & 0.1149 & 0.0884 & 0.1647 & 0.0889 & 0.0689 & 0.1394 & 0.1095 & 0.1903 & 0.0742 & 0.0944 & 0.1055 & 0.0990 & 0.1115 & 0.0995 & 0.1043 \\
\hline C1.4. & 0.0485 & 0.1149 & 0.0295 & 0.0549 & 0.0741 & 0.1205 & 0.0558 & 0.0547 & 0.1903 & 0.0989 & 0.0708 & 0.1055 & 0.0495 & 0.0040 & 0.0995 & 0.0781 \\
\hline C1.5. & 0.0324 & 0.0115 & 0.0147 & 0.0110 & 0.0148 & 0.1205 & 0.0040 & 0.0137 & 0.0119 & 0.0031 & 0.0039 & 0.0264 & 0.0049 & 0.0836 & 0.0047 & 0.0241 \\
\hline C1.6. & 0.0243 & 0.0115 & 0.0221 & 0.0078 & 0.0021 & 0.0172 & 0.0558 & 0.0156 & 0.0136 & 0.0247 & 0.0708 & 0.0044 & 0.0049 & 0.1115 & 0.0055 & 0.0261 \\
\hline C2.1. & 0.0485 & 0.0046 & 0.0177 & 0.0275 & 0.1037 & 0.0086 & 0.0279 & 0.0547 & 0.0238 & 0.0082 & 0.0047 & 0.0791 & 0.0062 & 0.1951 & 0.1326 & 0.0495 \\
\hline C2.2. & 0.4854 & 0.0115 & 0.0884 & 0.1098 & 0.1186 & 0.1205 & 0.0558 & 0.1095 & 0.0476 & 0.0494 & 0.1180 & 0.1319 & 0.1732 & 0.0557 & 0.2652 & 0.1294 \\
\hline C2.3. & 0.0485 & 0.0230 & 0.0442 & 0.0275 & 0.1186 & 0.1205 & 0.1115 & 0.2189 & 0.0952 & 0.1236 & 0.0944 & 0.0791 & 0.1980 & 0.0836 & 0.1326 & 0.1013 \\
\hline C2.4. & 0.0485 & 0.0459 & 0.0295 & 0.0137 & 0.1186 & 0.0172 & 0.0836 & 0.0547 & 0.0190 & 0.0247 & 0.0472 & 0.0044 & 0.0035 & 0.0139 & 0.0055 & 0.0353 \\
\hline C2.5. & 0.0324 & 0.0077 & 0.0221 & 0.0183 & 0.0889 & 0.0057 & 0.1394 & 0.0219 & 0.0238 & 0.0124 & 0.0236 & 0.0088 & 0.0049 & 0.0139 & 0.0083 & 0.0288 \\
\hline C2.6. & 0.0139 & 0.0115 & 0.0221 & 0.0137 & 0.0148 & 0.1033 & 0.0093 & 0.0219 & 0.0317 & 0.1483 & 0.0708 & 0.0264 & 0.0062 & 0.0093 & 0.1326 & 0.0424 \\
\hline C3.1. & 0.0194 & 0.1378 & 0.0221 & 0.0275 & 0.0741 & 0.0861 & 0.1115 & 0.0156 & 0.0119 & 0.1730 & 0.1180 & 0.1055 & 0.0247 & 0.0056 & 0.0047 & 0.0625 \\
\hline C3.2. & 0.0243 & 0.1149 & 0.0221 & 0.3844 & 0.0049 & 0.0043 & 0.0040 & 0.0547 & 0.0317 & 0.0494 & 0.0472 & 0.0791 & 0.1237 & 0.0279 & 0.0055 & 0.0652 \\
\hline C3.3. & 0.0485 & 0.1838 & 0.0295 & 0.0183 & 0.1037 & 0.1033 & 0.0070 & 0.0137 & 0.0238 & 0.1483 & 0.0944 & 0.0066 & 0.1732 & 0.1672 & 0.0332 & 0.0770 \\
\hline
\end{tabular}

Note: C1.1. Identity, C1.2. Authenticity, C1.3. Safety and well-being, C1.4. Sense of place, C1.5. Building gathering areas, C1.6. Sense of enjoyment, C2.1. Habitat and Natural preservation, C2.2. Pollution moderator, C2.3. Accessibility, C2.4. Dynamic site design, C2.5. Building walkable outdoor environment, C2.6. Providing facilities and amenities, C3.1. Mixed-use development, C3.2. Diversification, C3.3. Employment opportunity.

Table 5. Matrix of weightages for determining waterfront typologies' shares in tourism attraction.

\begin{tabular}{|c|c|c|c|c|c|c|c|c|c|c|c|c|c|c|c|c|}
\hline & C1.1. & C1.2. & C1.3. & C1.4. & C1.5. & C1.6. & C2.1. & C2.2. & C2.3. & C2.4. & $\mathrm{C} 2.5$. & C2.6. & C3.1. & C3.2. & C3.3. & Normalized Weightage \\
\hline Alt. 1 & 0.0416 & 0.0828 & 0.1121 & 0.0250 & 0.0257 & 0.1465 & 0.3461 & 0.1037 & 0.0859 & 0.0247 & 0.0817 & 0.2189 & 0.1278 & 0.0254 & 0.5022 & 0.1275 \\
\hline Alt. 2 & 0.2310 & 0.2099 & 0.3886 & 0.1604 & 0.1855 & 0.2391 & 0.1656 & 0.1339 & 0.2483 & 0.2099 & 0.1325 & 0.2902 & 0.0822 & 0.1667 & 0.2224 & 0.2107 \\
\hline Alt. 3 & 0.4726 & 0.0987 & 0.0310 & 0.4833 & 0.4020 & 0.1587 & 0.1140 & 0.0305 & 0.1636 & 0.2391 & 0.1582 & 0.0868 & 0.2961 & 0.1854 & 0.0388 & 0.1962 \\
\hline Alt. 4 & 0.1606 & 0.4191 & 0.0935 & 0.2256 & 0.2391 & 0.3226 & 0.1428 & 0.1859 & 0.4115 & 0.4024 & 0.4655 & 0.2419 & 0.2537 & 0.4091 & 0.0691 & 0.2410 \\
\hline Alt. 5 & 0.0662 & 0.0914 & 0.1283 & 0.0611 & 0.0960 & 0.0948 & 0.1767 & 0.0901 & 0.0316 & 0.0571 & 0.1187 & 0.0539 & 0.1373 & 0.0518 & 0.0279 & 0.0813 \\
\hline Alt. 6 & 0.0280 & 0.0981 & 0.2464 & 0.0446 & 0.0518 & 0.0383 & 0.0549 & 0.4560 & 0.0591 & 0.0668 & 0.0434 & 0.1083 & 0.1029 & 0.1616 & 0.1395 & 0.1434 \\
\hline
\end{tabular}

Note: C1.1. Identity, C1.2. Authenticity, C1.3. Safety and well-being, C1.4. Sense of place, C1.5. Building gathering areas, C1.6. Sense of enjoyment, C2.1. Habitat and Natural preservation, C2.2. Pollution moderator, C2.3. Accessibility, C2.4. Dynamic site design, C2.5. Building walkable outdoor environment, C2.6. Providing facilities and amenities, C3.1. Mixed-use development, C3.2. Diversification, C3.3. Employment opportunity, Alt. 1. The Commercial Waterfront, Alt. 2. The Educational and Environmental Waterfront, Alt. 3. The Recreational Waterfront, Alt. 4. The Historic Waterfront, Alt. 5. The Residential Waterfront, Alt. 6. The working and Transportation Waterfront. 


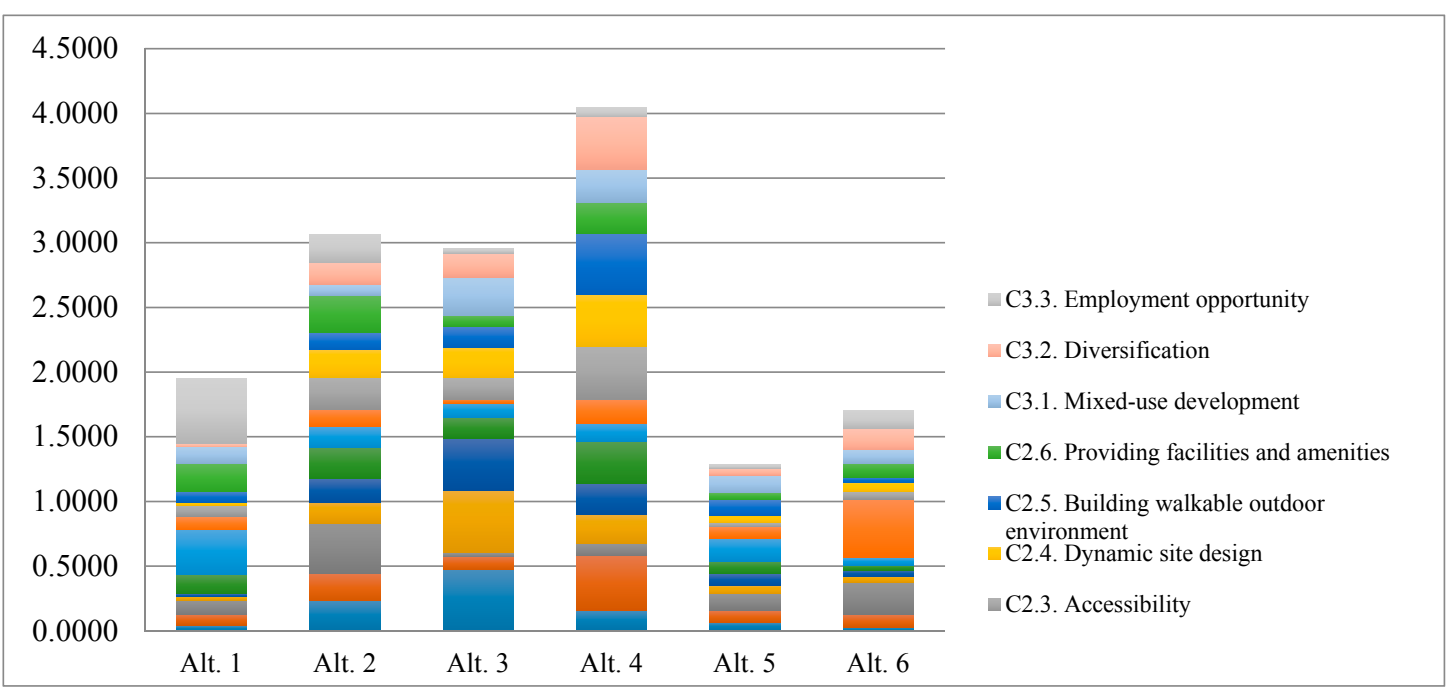

Figure 2. Cumulative weightage of waterfront typologies in tourism attraction (Note: Alt. 1. The Commercial Waterfront, Alt. 2. The Educational and Environmental Waterfront, Alt. 3. The Recreational Waterfront, Alt. 4. The Historic Waterfront, Alt. 5. The Residential Waterfront, Alt. 6. The working and Transportation Waterfront).

Referring to Tables 4 and 5, the Waterfront Sustainable Revitalization (SWR) assessment index was developed (Equation (5)). SWR index is a linear formula involves the criteria and the corresponding co-efficient. According to Table 4, the column 'weightage' was translated as co-efficient of the criteria. Also, according to Table 5, the Historic Waterfront has the highest potential to attract tourism; hence the data for Recreational Waterfront (i.e., Alt. 4) has been extracted and employed into the SWR indexing formula (Equation 5).

$$
\begin{gathered}
\text { SWR Index }=\sum \text { Index Social and cultural }+ \text { Index }_{\text {Environmental }}+\text { Index }_{\text {Economic and functional }} \\
\text { SWR Index }=\sum\left[\left(a_{1 . i} X+b_{1 . i}\right)+\left(a_{2 . j} Y+b_{2 . j}\right)+\left(a_{3 . k} Z+b_{3 . k}\right)\right]
\end{gathered}
$$

where $a$ coefficient of waterfront revitalization criteria (Extracted from Table 4 ); $b$; consistent value (i.e., weightage) (Extracted from Table 5); $i$ Social and cultural waterfront revitalization criteria (for: 1 , $2,3, \ldots, 6) ; j$ Environmental waterfront revitalization criteria (for: $1,2,3, \ldots, 6$ ); $k$ Economic and functional waterfront revitalization criteria (for: $1,2,3$ ); $X$ Weight of the criterion " $I$ " of the Social and cultural dimension assigned by the experts through close group discussion; $Y$ Weight of the criterion " $j$ " of the Environmental dimension assigned by the experts through close group discussion; $Z$ Weight of the criterion " $j$ " of the Economic and functional dimension assigned by the experts through close group discussion.

\section{Implementation and Results}

In the second phase, the research has validated the SWR assessment index model through a case study. The SWR index can be applied to different waterfronts with diverse urban texture and climate conditions around the world. The case study conducted in this research is Bandar Maharani waterfront in Muar, Malaysia (Figure 3). Muar is one of significant districts and one of the most popular tourist attractive sites in Malaysia. The Muar district is known as Royal City of Johor (also called as the City Pension) and is the fourth largest city of the state of Johor; after Johor Bahru, Batu Pahat and Kluang. Bandar Maharani in Muar is rich in history as mentioned in many historical records and archaeological works. There are many local attractions and places of interest in Muar; for example, historical buildings from the pre war, tourism products, religious buildings and worship places. Bandar Maharani has an outstanding landmark built in the middle of round-about (by 1880s), which looks like a gate-shaped 
ivory and a crown above it. Bandar Maharani has numbers of government buildings, shop-houses and mosques characterized the colonial era still stands. One of the more popular spots in Bandar Maharani is Tanjung Emas (literally translated as, Cape of Gold or Golden Cape or Gold Cape) located nearby Muar riverfront. Design concept of Bandar Maharani is the royal town (see Figure 4). The riverfront encourages the tourism which enhances the economic situation of the city. Softscape plantings (such as Boungainvillea species and heritage trees) provide aesthetic value, especially at pedestrian walkways.

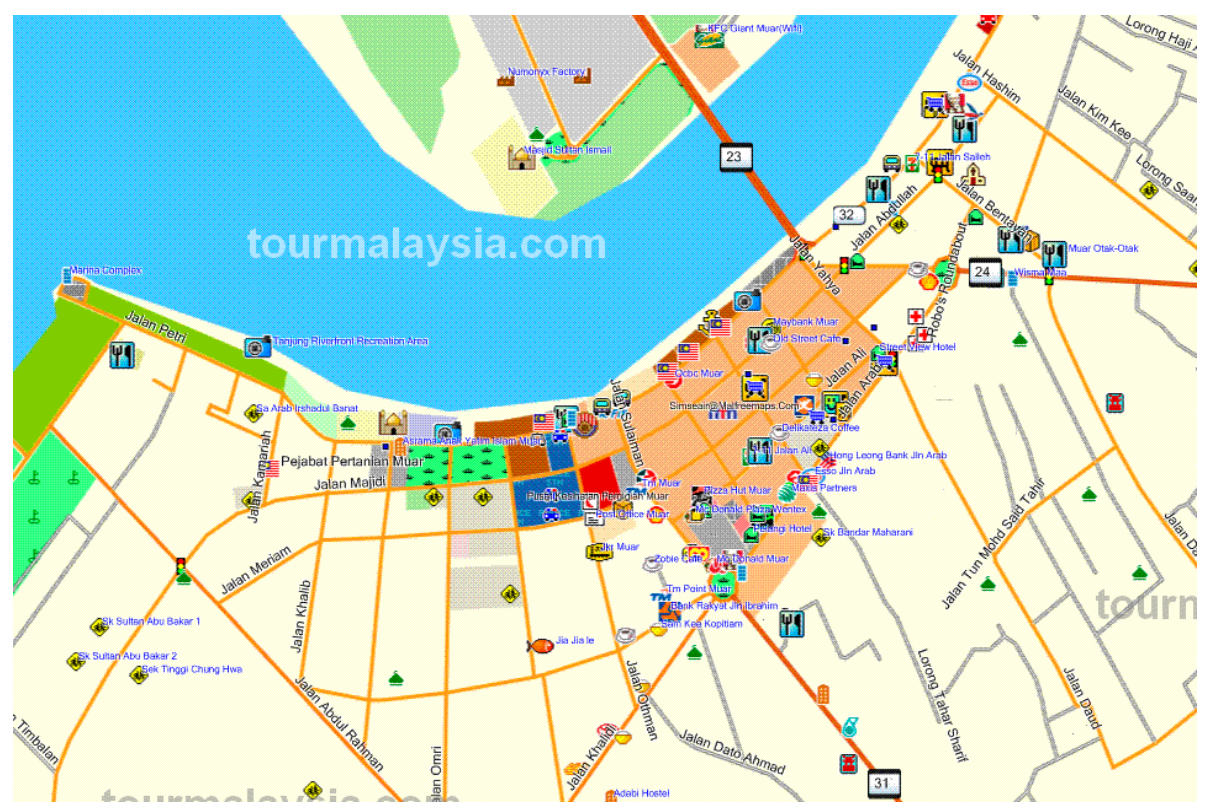

Figure 3. The map shows the location plan of Bandar Maharani, Muar. (Source: www.tourmalaysia. com/wp-content/uploads/2009/01/muar-city-map2).

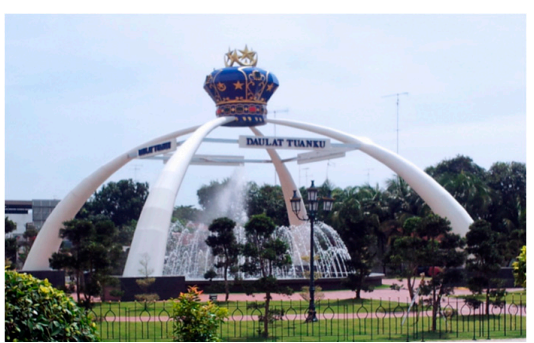

(a)

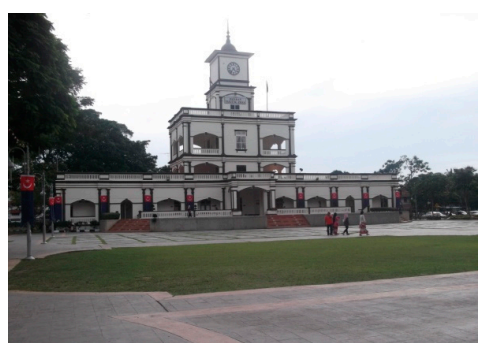

(b)

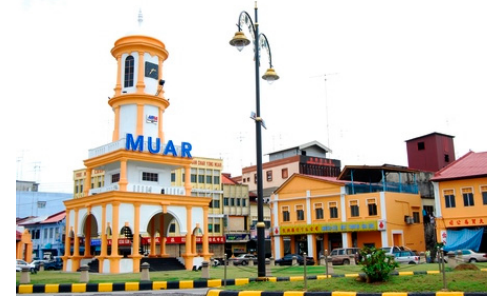

(c)

Figure 4. The landmarks of Bandar Maharani, Muar Royal Town: (a) The gate-shaped ivory crown, (b) Dataran Tanjung Emas, (c) Clock Tower.

The research conducted an expert input study to validate the SWR index's implementation in Bandar Maharani, Muar. The expert input study has applied the Weighted Sum Method (WSM). A field expert structured close group discussion was conducted for this expert input study. Fishburn [61] expresses WSM is a simple way to convert multi-objective optimization to a single-objective optimization. Marler and Arora [62] stated that WSM works well by multiplying each objective with a user given weight. The WSM formula used in the calculation procedure is as shown in Equation (5);

$$
\operatorname{WSM}\left(a_{i}\right)=\left(\sum_{j=1}^{n} w_{j}\right) a_{i} \quad(\text { for } i=1,2,3, \ldots, m)
$$


where " $w_{j}$ " referred to assigned weight by decision maker in close group discussion for sub-issue of discussion by participants number " $j$ ", " $a_{i}$ " is sub-issue of discussion with the given ordering number of " $i$ ".

Equation (6) indicates the consensus calculation. The consensus was accepted if more than $70 \%$ saturation on experts' judgment was observed.

$$
\operatorname{WSM}\left(a_{i}\right) / \operatorname{WSM}(a)_{\max }=\text { Consensus in } \%
$$

where $\operatorname{WSM}(a)_{\max }$, refers to maximum sum of possible weight that can be given for one sub-issue.

A structured fixed format self-reporting questionnaire form was designed filled up by the experts. The interviews rated the landscaped design criteria and sub-criteria based on likert 5-point scaling of 1 for weak to 5 for excellent. Based on WSM's purposive sampling method the expert input study process has been conducted by involving 5 experts who have knowledge and experiences in waterfront development, conservation and revitalization. SWR Index was calculated for the Bandar Maharani refereed to Table 6. As a result, Bandar Maharani, Muar received 4.678 SWR index scoring.

$$
\begin{gathered}
\text { SWR Index }_{\text {implementation }}=\Sigma \text { Index }_{\text {Social and cultural }}+\text { Index }_{\text {Environmental }}+\text { Index }_{\text {Economic and functional }} \\
\text { SWR Index } x_{\text {implementation of Social and cultural }}=(0.1272 \times 0.95+0.1606)+(0.0487 \times 0.92+0.4191) \\
+(0.1043 \times 0.92+0.0935)+(0.0781 \times 0.64+0.2256)+(0.02410 .84+0.2391) \\
+(0.0261 \times 0.88+0.3226)=0.2814+0.4639+0.1894+0.2755+0.2593+0.3455=1.6256 \\
\text { SWR Index } \text { implementation of Environmental }=(0.0495 \times 0.72+0.1428)+(0.1294 \times 0.76+0.1859) \\
+(0.1013 \times 0.76+0.4115)+(0.0353 \times 0.68+0.4024)+(0.0288 \times 0.92+0.4655) \\
+(0.0424 \times 0.92+0.2419)=0.1784+0.2842+0.4884+0.4264+0.4919+0.2809=2.1502 \\
\text { SWR Index } \text { implementation of Economic and functional }=(0.0625 \times 0.88+0.2537)+(0.0652 \times 0.92+0.4091) \\
+(0.0770 \times 0.72+0.0691)=0.3087+0.4690+0.1245=0.9022 \\
\text { SWR Index implementation }=1.6256+2.1502+0.9022=4.678 .
\end{gathered}
$$

The SWR Index model has identified five grades as A, B, C, D and E corresponding to 5 scoring ranges (see Table 7). Grade A has the highest value which was calculated as the maximum value; while grade $E$ has the lowest value as calculated as maximum value. The flowing presents the calculation of SWR Index maximum (Max). In SWR Index maximum the weight of all criteria $(X, Y$ and $Z)$ was assumed as 1. In fact, the SWR Index minimum (Min) equals to 0.2 of maximum (Max).

$$
\begin{aligned}
& \text { SWR Index } \operatorname{Max} \cong 5.50 \\
& \text { SWR Index }_{\text {Min }}=5.50 \times 0.2=1.10
\end{aligned}
$$

According to SWR Index grades interpretations (Table 7) Bandar Maharani has placed in Grade A: Superior. So, Bandar Maharani is a well-designed waterfront which satisfies users, where needs minor improvements. 
Table 6. WSM results Experts inputs on the WSR index implementation in Bandar Maharani, Muar.

\begin{tabular}{|c|c|c|c|c|c|c|c|c|}
\hline \multirow{2}{*}{ Sustainability Criteria } & \multirow{2}{*}{ Sub-Criteria } & \multicolumn{5}{|c|}{ Expert Panels } & \multirow{2}{*}{$W S M(a)_{\max }$ of Criteria } & \multirow{2}{*}{ Cons } \\
\hline & & $\mathrm{EX}_{1}$ & $\mathrm{EX}_{2}$ & $\mathrm{EX}_{3}$ & $\mathrm{EX}_{4}$ & $\mathrm{EX}_{5}$ & & \\
\hline \multirow{6}{*}{$\begin{array}{l}\text { C1. Social and Cultural } \\
\text { Revitalization }\end{array}$} & C1.1. Identity & 5 & 5 & 5 & 4 & 5 & 25 & 0.96 \\
\hline & C1.2. Authenticity & 5 & 5 & 4 & 4 & 5 & 25 & 0.92 \\
\hline & C1.3. Safety and access & 4 & 5 & 4 & 5 & 5 & 25 & 0.92 \\
\hline & C1.4. Sense of place & 3 & 4 & 3 & 2 & 4 & 25 & 0.64 \\
\hline & C1.5. Building gathering areas & 5 & 4 & 4 & 3 & 5 & 25 & 0.84 \\
\hline & C1.6 Sense of enjoyment & 5 & 5 & 3 & 4 & 5 & 25 & 0.88 \\
\hline \multirow{6}{*}{$\begin{array}{l}\text { C2. Physical and } \\
\text { Environment } \\
\text { Revitalization }\end{array}$} & C2.1. Habitat and Natural preservation & 3 & 4 & 3 & 4 & 4 & 25 & 0.72 \\
\hline & C2.2. Pollution moderator & 3 & 3 & 5 & 4 & 4 & 25 & 0.76 \\
\hline & C2.3. Accessibility & 4 & 4 & 5 & 4 & 2 & 25 & 0.76 \\
\hline & C2.4. Dynamic site design & 5 & 4 & 2 & 2 & 4 & 25 & 0.68 \\
\hline & C2.5. Building walkable outdoor environment & 5 & 4 & 5 & 4 & 5 & 25 & 0.92 \\
\hline & C2.6. Providing facilities and amenities & 4 & 3 & 5 & 4 & 3 & 25 & 0.76 \\
\hline \multirow{3}{*}{$\begin{array}{c}\text { C3. Economic and } \\
\text { Functional Revitalization }\end{array}$} & C3.1. Mixed-use development & 5 & 4 & 5 & 5 & 3 & 25 & 0.88 \\
\hline & C3.2. Diversification & 4 & 5 & 4 & 3 & 5 & 25 & 0.92 \\
\hline & C3.3. Employment opportunity & 3 & 4 & 4 & 4 & 3 & 25 & 0.72 \\
\hline
\end{tabular}

Note: EX-Expert; Cons.-refers to consensus calculated based on Equation (7).

Table 7. SWR Index grades interpretations.

\begin{tabular}{ccl}
\hline Grades & Scoring & \multicolumn{1}{c}{ Description and Recommendations } \\
\hline $\begin{array}{c}\text { Grade A: Superior } \\
\text { Grade B: Good }\end{array}$ & $\begin{array}{l}\text { W.51-5.50 } \\
\text { Grade C: Fair }\end{array}$ & $\begin{array}{l}\text { Well-designed waterfront which satisfies users; Minor improvements, if any, needed. } \\
\text { Constructed waterfront which accommodates users; Minor improvements may improve to superior rating }\end{array}$ \\
Grade D: Poor & $1.10-2.10$ & $\begin{array}{l}\text { Usable waterfront which some users do not feel high level of vitality; improvement, such as better facilities and } \\
\text { amenities, almost needed. } \\
\text { Usable waterfront which many users do not feel high level of vitality; significant improvement, such as lack of facilities } \\
\text { and amenties probably needed } \\
\text { Non-usable waterfront which users do not feel even medium level of vitality and has sub-standard conditions combined } \\
\text { with heavy traffic; Should be improved. }\end{array}$ \\
\hline
\end{tabular}




\section{Discussions}

There are very few studies investigating the role of waterfront revitalization for tourism attractions. This study found out the revitalized historic waterfront can intensively contribute for attracting tourism compared to other waterfront typologies. This results is supported by Rodwell [63] and Simon [64]. They have significantly addressed this issue in an international conference held in Liverpool, in 2008. In that conference, Rodwell [63] states "historic waterfronts act as catalysts for economic regeneration and enable people to reconnect with historic quayside areas whether for business or social exchange, residence or leisure". And, Simon [64] states that the character of historic waterfronts has great cultural and economic value and "these exciting environments are a magnet for tourism". Also, Rodwell [63] expresses historic waterfronts "... not only serve to consolidate the identity of the city but also bring economic benefits which help to sustain the city as a whole". On the characteristics of historic waterfronts, Rodwell [63] states that historic waterfronts inspire cultural buildings and old architecture and recall their identity by highly creative examples of modern architecture in order to promote people's interaction and connection with their local culture. Moreover, Rodwell [63] states old commercial areas become vital economic places and the population does not tend to move to the new town areas. According to previous studies, instead of condemning old waterfront structures to decay, some cities are taking efforts to preserve and suggest adaptive reuse of the buildings and areas where they can bring profits to the community's economy [1]. Currently, there is a greater interest in more culturally and leisurely oriented activities for the waterfront with the use of heritage buildings for tourism-related activities and a preference for urban settings.

The goal of the revitalization strategy is to create a long-term vision for improving the physical, social, economic and environmental conditions of the waterfront to a vibrant and viable place. Kostopoulou [17] states that most of the revitalization projects resulted in the enhanced and improved quality of life, a stronger sense of community and distinctive identity and character for users (residents and visitors). According to Al-hagla [65] revitalization benefits the sustainability perspectives as it; (i) transforms a town into a significant place with a distinctive identity and character, (ii) enhances the economic development opportunity; and (iii) enhances the quality of life by improving the environment. As described by Kostopoulou [17], waterfront revitalization is important to inspire the city's image and to avoid the city to being destroyed, damaged and abandoned. Besides, revitalization helps to enhance the image of the place and improves the economic development opportunity at the same time [17]. The revitalization strategy aids "to stimulate, facilitate and extend people's understanding of place so that empathy towards heritage, conservation, culture and landscape can be developed" [20]. Indeed, improving the appearance of an area is through recalling the historical identity values [66], which benefit tourists and residents alike social and cultural revitalization. Preserving built features such as gazebos, grottoes, bridges, fences, benches, lighting, drinking fountain, playground equipment, statuary and other types of amenities is important in defining the overall identity values of the revitalized waterfront $[67,68]$. The current research has found out recalling the identity plays an important role in attracting visitors to historical waterfronts by conserving and preserving of old buildings with enhancement on the traditional commercial activities, building attractive streetscape, artworks and functional spaces. Hagerman [14] states that preserving the habitat and native planting can promote the place identity, which has been indicated by this research, as well.

This research expresses that pollution moderator should be significantly considered in historical waterfront revitalization, beside habitat and natural preservation. Waterfront site has to absorb the prevailing winds and sea breezes for removing the pollutants by airflow and circulation [13]. Therefore, the compatible land uses, height and orientation of buildings, space in-between buildings and open spaces have to be considered in the historic waterfront revitalization plan [69]. Moreover, this research found out the authenticity of the historic waterfront can extensively contribute for attracting tourist. This has been also supported by Pendlebury et al. [70] who express that the site should provide friendly, comfortable and secure facilities that generate the authenticity. The authenticity leads people, especially tourists, to explore the area and promote social contacts [70]. Creating inclusive circulation systems 
can also enhance the permeability to the historical site and hence, can enhance its authenticity [71]. Waitt [72] declares that development of major urban networking infrastructures (such as road and highways) may block and decrease permeability and therefore, authenticity to the open view of the waterfront. Furthermore, this research determined that mixed-use development is the most important economic driver for attracting tourists in historical waterfronts. In this regards, Ebbe [47], a mixed-use streetscape along the old buildings with commercial activities can assist the economic development integrated with social development. Portman et al. [69] states that pedestrian linkage in-between the buildings is much more important to connect and enhance mixed-use development.

This research has developed the SWR index using AHP method. AHP's primary functions (i.e., structuring complexity, measurement and synthesis) make it an applicable method for waterfront revitalization assessment. AHP structures the complexity, measurement and synthesis over multiple dimensions. AHP allows policy-makers to make decisions more simply and intimately about the complex and complicated multiple waterfront development/redevelopment. In this research, the AHP aided to get the weightage of all features involved in the SWR index. AHP as a hierarchical-based method used ratio-scale priorities (i.e., weightage) in waterfront revitalization assessment. Through AHP application, the priorities of the waterfront revitalization criteria have been determined by multiplying the priorities of the parent criteria of the same level. The AHP used ratio-scale priorities for the lowest level of the hierarchy construct (i.e., Alternatives). Particularly, the ratio-scaling of AHP made the resource allocation for future waterfront development and corrective actions possible and implacable.

The SWR index was implemented in a case study to be validated. The weightages assigned by AHP have played as the coefficient in the SWR index. Through implementation of SWR index the value for each coefficient has been indicated (which these values shall be varied in each case study). The SWR index model has been implemented in Bandar Maharani, Muar, Malaysia. Referring to Table 6, Bandar Maharani, Muar has received less than 75\% for some sub-criteria. Means, the Bandar Maharani, Muar has a minor lacking for tourism attraction in terms of C1.4. Sense of place, C2.1. Habitat and Natural preservation, C2.5. Dynamic site design and C3.3. Employment opportunity. In this regards, the following improvements have been recommended by the expert for improving tourism attraction at Bandar Maharani;

(I) Considerations for Social and Cultural Revitalization Sense of Place:

- Significant historical structures and landmarks should preserve and conserve.

- New developments or major improvement works should complement with the old urban fabric and the street identity and special characteristic should preserve or retain.

- The site has to accommodate for recreational activities, traditional activities and entertainment activities to support royal town identity.

(II) Considerations of Physical and Environmental Revitalization Habitat and Natural preservation:

- Living plants shall be used. If drought-tolerant plant materials are not used permanent irrigation shall be required.

- Low maintenance and living ground-cover should be used wherever possible as well as grass.

- Gravel, river rock, pavement or similar non-living materials should not be used as ground cover substitutes but may be allowed as accent within landscape planting areas.

- Plant material should be used to enhance street corners and intersections but should not interfere with the "site clear-view triangle" set forth in the code. 
Dynamic site design:

- Promote visual interest of waterfront outlook in terms of land use, built form and landscape treatments.

- Pedestrian oriented promenade with look out points or view corridor should be promoted.

- Horizontal elements such as special designed paving pattern need to be contracted.

- A particular paving material throughout a series of spaces would provide continuity and sometimes used to define the direction and hierarchy.

(III) Considerations Economic and Functional Revitalization:

Employment opportunity:

- The site has to promote the tourism industry by encouraging them to visit historical sites and landmarks.

- Persuading people to participate in government rehabilitation projects.

\section{Conclusions}

The revitalization strategy in waterfronts for tourism attraction is very important which revives the place with a new vital life. In waterfront revitalization, the aspects of the physical environment, social, community, economic and functional should be taken into account to make a sustainable and vital place. Streetscape planning, open space design, conservation and preservation of heritage values and historic environment should be considered in waterfront revitalization. Besides, functional spaces for activities, either commercial or non-commercial activities, should be considered to enhance and improve the economic development of the places for tourism attractions.

This study has developed the Sustainable Historic Waterfront Revitalization index assessment model as a decision support tool to revitalize the waterfront for users, particularly, tourist and visitors. For developing this index model, the study has conducted an exploratory analysis to find out the importance level of each feature using AHP decision-making method. AHP has demonstrated its capacity to analyze and synthesize the relative priorities (weightage) and to calculate a ranking score of all elements (i.e., criteria, sub-criteria and alternatives). Applying AHP allowed us to use its capability and usability to compare those elements pair-wisely and indicate the best alternatives accurately. This research found out the historic waterfront has the highest potential in tourism attraction among other typologies (i.e., Commercial Waterfront, Educational and Environmental Waterfront, Recreational Waterfront, Residential Waterfront and Working and Transportation Waterfront). Also, research found out pollution moderator is the most important criterion for tourist attraction in the revitalized waterfront $\left(\mathrm{W}_{\mathrm{C} 2.2}=0.1294\right)$, followed by Identity $\left(\mathrm{W}_{\mathrm{C} 1.2}=0.1272\right)$ and Safety and well-being $\left(\mathrm{W}_{\mathrm{C} 1.3}=0.1043\right)$.

The end users of the research outputs would be both professional experts and practitioners. Professionals, including policy makers and top-managers, urban designers, urban planners, landscape planners, transportation planners, consultants, authorities, contractors and academicians may use the research output for their purposes regarding fulfilling the requirement of waterfront sustainability accreditation.

The research has faced two types of limitation in the study. First, the access to available data source; the research suggests if more available data sources were available more waterfront revitalization features might be identified. Secondly, the limit knowledge and experience of invited experts in using GGDM method; the invited experts have not practiced the GGDM method before.

As future works, although AHP has its advantages for determining priority scores of elements, it can be coupled with other methods (for instance, GIS (Geographic Information System), SEM (structural equation modelling), SNA (social network analysis), etc.) in future works. Coupling different methods can reduce inconsistencies and errors, while increase coefficient's accuracy. However, it may never end, research in this area of decision-making is still critical and very valuable with its 
scientific and practical applications. In addition, the SWR model can be promoted in the form of a stand-alone and/or web-based software which the end-users can use it more applicably and inclusively. Moreover, further research can be conducted especially within two categories. Firstly, the macro-scale studies which address upstream research parallel to the current study. The macro-scale studies may focus on the following approaches; formulating correlation of old town revitalization and landscape planning strategies criteria and developing a framework of waterfront revitalization through landscape planning strategies. Secondly, the micro-scale studies which address downstream research in more detail and continuation of the further development of the current study. Besides, the perception of the tourists or public people would be considered as the non-experts in future studies.

Acknowledgments: The authors would like to thank the Malaysia Ministry of Science, Technology, Innovation (MOSTI) grant vote NO. R.J130000.7922.4S123. Also, the authors appreciate these organizations for their supports and contributions and Research Management Center at Universiti Teknologi Malaysia.

Author Contributions: The authors, Ali Keyvanfar, Arezou Shafaghat, Sapura Mohamad, Hamidah Ahmad, Nurul Hidayah Mohd Derus and Majid Khorami have all contributed to preparing this manuscript and Mu'azu Mohammed Abdullahi contributed towards structuring it.

Conflicts of Interest: The authors declare no conflict of interest.

\section{Appendix A}

Table A1. Normalized supermatrix of waterfront typologies on each sub-criterion.

\begin{tabular}{|c|c|c|c|c|c|c|}
\hline \multicolumn{7}{|c|}{ Normalized supermatrix of waterfront typologies on the indication of C1.1. Identity } \\
\hline Alt. 1. & Alt. 2. & Alt. 3. & Alt. 4. & Alt. 5. & Alt. 6. & Weightage (W) \\
\hline 0.0353 & 0.0149 & 0.0672 & 0.0106 & 0.0106 & 0.1111 & 0.0416 \\
\hline 0.2471 & 0.1040 & 0.0756 & 0.4455 & 0.2544 & 0.2593 & 0.2310 \\
\hline 0.3176 & 0.8317 & 0.6050 & 0.4455 & 0.3392 & 0.2963 & 0.4726 \\
\hline 0.2471 & 0.0173 & 0.1008 & 0.0743 & 0.3392 & 0.1852 & 0.1606 \\
\hline 0.1412 & 0.0173 & 0.0756 & 0.0093 & 0.0424 & 0.1111 & 0.0662 \\
\hline 0.0118 & 0.0149 & 0.0756 & 0.0149 & 0.0141 & 0.0370 & 0.0280 \\
\hline \multicolumn{7}{|c|}{ Normalized supermatrix of waterfront typologies on the indication C1.2. Authenticity } \\
\hline Alt. 1. & Alt. 2. & Alt. 3. & Alt. 4. & Alt. 5 . & Alt. 6. & Weightage (W) \\
\hline 0.0421 & 0.0182 & 0.0073 & 0.0663 & 0.2637 & 0.0993 & 0.0828 \\
\hline 0.2947 & 0.1271 & 0.2036 & 0.0884 & 0.1978 & 0.3475 & 0.2099 \\
\hline 0.2947 & 0.0318 & 0.0509 & 0.0758 & 0.1319 & 0.0071 & 0.0987 \\
\hline 0.3368 & 0.7625 & 0.3564 & 0.5306 & 0.3297 & 0.1986 & 0.4191 \\
\hline 0.0105 & 0.0424 & 0.0255 & 0.1061 & 0.0659 & 0.2979 & 0.0914 \\
\hline 0.0211 & 0.0182 & 0.3564 & 0.1327 & 0.0110 & 0.0496 & 0.0981 \\
\hline \multicolumn{7}{|c|}{ Normalized supermatrix of waterfront typologies on the indication of C1.3. Safety and well-being } \\
\hline Alt. 1. & Alt. 2. & Alt. 3. & Alt. 4. & Alt. 5. & Alt. 6. & Weightage $(W)$ \\
\hline 0.0599 & 0.1618 & 0.0769 & 0.3429 & 0.0096 & 0.0216 & 0.1121 \\
\hline 0.1796 & 0.4855 & 0.2692 & 0.2743 & 0.3462 & 0.7766 & 0.3886 \\
\hline 0.0299 & 0.0694 & 0.0385 & 0.0171 & 0.0096 & 0.0216 & 0.0310 \\
\hline 0.0120 & 0.1214 & 0.1538 & 0.0686 & 0.1731 & 0.0324 & 0.0935 \\
\hline 0.3593 & 0.0809 & 0.2308 & 0.0229 & 0.0577 & 0.0185 & 0.1283 \\
\hline 0.3593 & 0.0809 & 0.2308 & 0.2743 & 0.4038 & 0.1294 & 0.2464 \\
\hline \multicolumn{7}{|c|}{ Normalized supermatrix of waterfront typologies on the indication of C1.4. Sense of place } \\
\hline Alt. 1. & Alt. 2. & Alt. 3. & Alt. 4. & Alt. 5. & Alt. 6. & Weightage (W) \\
\hline 0.0323 & 0.0092 & 0.0682 & 0.0148 & 0.0120 & 0.0137 & 0.0250 \\
\hline 0.2258 & 0.0647 & 0.0877 & 0.0148 & 0.2410 & 0.3288 & 0.1604 \\
\hline 0.2903 & 0.4526 & 0.6139 & 0.8288 & 0.3855 & 0.3288 & 0.4833 \\
\hline 0.2258 & 0.4526 & 0.0767 & 0.1036 & 0.2892 & 0.2055 & 0.2256 \\
\hline 0.1290 & 0.0129 & 0.0767 & 0.0173 & 0.0482 & 0.0822 & 0.0611 \\
\hline 0.0968 & 0.0081 & 0.0767 & 0.0207 & 0.0241 & 0.0411 & 0.0446 \\
\hline
\end{tabular}


Table A1. Cont.

\begin{tabular}{|c|c|c|c|c|c|c|}
\hline \multicolumn{7}{|c|}{ Normalized supermatrix of waterfront typologies on the indication of C1.5. Building gathering areas } \\
\hline Alt. 1. & Alt. 2. & Alt. 3. & Alt. 4. & Alt. 5. & Alt. 6. & Weightage (W) \\
\hline 0.0294 & 0.0167 & 0.0577 & 0.0321 & 0.0108 & 0.0076 & 0.0257 \\
\hline 0.2059 & 0.1168 & 0.0769 & 0.2246 & 0.2595 & 0.2290 & 0.1855 \\
\hline 0.2353 & 0.7010 & 0.4615 & 0.4492 & 0.2595 & 0.3053 & 0.4020 \\
\hline 0.2059 & 0.1168 & 0.2308 & 0.2246 & 0.3892 & 0.2672 & 0.2391 \\
\hline 0.1765 & 0.0292 & 0.1154 & 0.0374 & 0.0649 & 0.1527 & 0.0960 \\
\hline 0.1471 & 0.0195 & 0.0577 & 0.0321 & 0.0162 & 0.0382 & 0.0518 \\
\hline \multicolumn{7}{|c|}{ Normalized supermatrix of waterfront typologies on the indication of C1.6 Sense of enjoyment } \\
\hline Alt. 1. & Alt. 2. & Alt. 3. & Alt. 4. & Alt. 5. & Alt. 6. & Weightage (W) \\
\hline 0.0383 & 0.7619 & 0.0106 & 0.0495 & 0.0067 & 0.0118 & 0.1465 \\
\hline 0.0048 & 0.0952 & 0.4460 & 0.3956 & 0.2811 & 0.2118 & 0.2391 \\
\hline 0.2679 & 0.0159 & 0.0743 & 0.0659 & 0.2811 & 0.2471 & 0.1587 \\
\hline 0.3062 & 0.0952 & 0.4460 & 0.3956 & 0.3748 & 0.3176 & 0.3226 \\
\hline 0.2679 & 0.0159 & 0.0124 & 0.0495 & 0.0469 & 0.1765 & 0.0948 \\
\hline 0.1148 & 0.0159 & 0.0106 & 0.0440 & 0.0094 & 0.0353 & 0.0383 \\
\hline \multicolumn{7}{|c|}{ Normalized supermatrix of waterfront typologies on the indication of C2.1. Habitat and Natural Preservation } \\
\hline Alt. 1. & Alt. 2. & Alt. 3. & Alt. 4. & Alt. 5. & Alt. 6. & Weightge (W) \\
\hline 0.1191 & 0.7636 & 0.5120 & 0.6377 & 0.0271 & 0.0169 & 0.3461 \\
\hline 0.0149 & 0.0955 & 0.1920 & 0.1822 & 0.2715 & 0.2373 & 0.1656 \\
\hline 0.0149 & 0.0318 & 0.0640 & 0.0304 & 0.2715 & 0.2712 & 0.1140 \\
\hline 0.0170 & 0.0477 & 0.1920 & 0.0911 & 0.2715 & 0.2373 & 0.1428 \\
\hline 0.5957 & 0.0477 & 0.0320 & 0.0456 & 0.1357 & 0.2034 & 0.1767 \\
\hline 0.2383 & 0.0136 & 0.0080 & 0.0130 & 0.0226 & 0.0339 & 0.0549 \\
\hline
\end{tabular}

Normalized supermatrix of waterfront typologies on the indication of C2.2. Pollution moderator

\begin{tabular}{|c|c|c|c|c|c|c|}
\hline Alt. 1. & Alt. 2. & Alt. 3. & Alt. 4. & Alt. 5 . & Alt. 6. & Weightage (W) \\
\hline 0.0427 & 0.0072 & 0.1724 & 0.0278 & 0.3015 & 0.0707 & 0.1037 \\
\hline 0.3419 & 0.0580 & 0.2759 & 0.0417 & 0.0151 & 0.0707 & 0.1339 \\
\hline 0.0085 & 0.0072 & 0.0345 & 0.0417 & 0.0201 & 0.0707 & 0.0305 \\
\hline 0.2564 & 0.2319 & 0.1379 & 0.1667 & 0.1809 & 0.1414 & 0.1859 \\
\hline 0.0085 & 0.2319 & 0.1034 & 0.0556 & 0.0603 & 0.0808 & 0.0901 \\
\hline 0.3419 & 0.4638 & 0.2759 & 0.6667 & 0.4221 & 0.5657 & 0.4560 \\
\hline \multicolumn{7}{|c|}{ Normalized supermatrix of waterfront typologies on the indication of C2.3. Accessibility } \\
\hline Alt. 1. & Alt. 2. & Alt. 3. & Alt. 4. & Alt. 5. & Alt. 6. & Weightage (W) \\
\hline 0.0489 & 0.0192 & 0.0157 & 0.0741 & 0.1923 & 0.1653 & 0.0859 \\
\hline 0.2934 & 0.1149 & 0.5669 & 0.0741 & 0.1923 & 0.2479 & 0.2483 \\
\hline 0.2934 & 0.0192 & 0.0945 & 0.1728 & 0.1538 & 0.2479 & 0.1636 \\
\hline 0.3423 & 0.8046 & 0.2835 & 0.5185 & 0.2308 & 0.2893 & 0.4115 \\
\hline 0.0098 & 0.0230 & 0.0236 & 0.0864 & 0.0385 & 0.0083 & 0.0316 \\
\hline 0.0122 & 0.0192 & 0.0157 & 0.0741 & 0.1923 & 0.0413 & 0.0591 \\
\hline \multicolumn{7}{|c|}{ Normalized supermatrix of waterfront typologies on the indication of C2.4. Dynamic site design } \\
\hline Alt. 1. & Alt. 2. & Alt. 3. & Alt. 4. & Alt. 5. & Alt. 6. & Weightage (W) \\
\hline 0.0278 & 0.0150 & 0.0215 & 0.0619 & 0.0153 & 0.0068 & 0.0247 \\
\hline 0.2500 & 0.1352 & 0.0572 & 0.1652 & 0.3206 & 0.3311 & 0.2099 \\
\hline 0.2222 & 0.4056 & 0.1717 & 0.1239 & 0.2748 & 0.2365 & 0.2391 \\
\hline 0.2222 & 0.4056 & 0.6867 & 0.4956 & 0.3206 & 0.2838 & 0.4024 \\
\hline 0.0833 & 0.0193 & 0.0286 & 0.0708 & 0.0458 & 0.0946 & 0.0571 \\
\hline 0.1944 & 0.0193 & 0.0343 & 0.0826 & 0.0229 & 0.0473 & 0.0668 \\
\hline \multicolumn{7}{|c|}{$\begin{array}{l}\text { Normalized supermatrix of waterfront typologies on the indication of C2.5. Building walkable } \\
\text { outdoor environment }\end{array}$} \\
\hline Alt. 1. & Alt. 2. & Alt. 3. & Alt. 4. & Alt. 5. & Alt. 6. & Weightage (W) \\
\hline 0.0495 & 0.0935 & 0.0411 & 0.0635 & 0.0156 & 0.2273 & 0.0817 \\
\hline 0.0495 & 0.0935 & 0.1644 & 0.0726 & 0.1875 & 0.2273 & 0.1325 \\
\hline 0.1980 & 0.0935 & 0.1644 & 0.1694 & 0.1875 & 0.1364 & 0.1582 \\
\hline 0.3960 & 0.6542 & 0.4932 & 0.5082 & 0.4688 & 0.2727 & 0.4655 \\
\hline 0.2970 & 0.0467 & 0.0822 & 0.1016 & 0.0938 & 0.0909 & 0.1187 \\
\hline 0.0099 & 0.0187 & 0.0548 & 0.0847 & 0.0469 & 0.0455 & 0.0434 \\
\hline
\end{tabular}


Table A1. Cont.

\begin{tabular}{|c|c|c|c|c|c|c|}
\hline \multicolumn{7}{|c|}{$\begin{array}{l}\text { Normalized supermatrix of waterfront typologies on the indication of C2.6. Providing facilities } \\
\text { and amenities }\end{array}$} \\
\hline Alt. 1. & Alt. 2. & Alt. 3. & Alt. 4. & Alt. 5. & Alt. 6. & Weightage (W) \\
\hline 0.0701 & 0.8068 & 0.3902 & 0.0192 & 0.0156 & 0.0117 & 0.2189 \\
\hline 0.0100 & 0.1153 & 0.2927 & 0.8085 & 0.2344 & 0.2802 & 0.2902 \\
\hline 0.0088 & 0.0192 & 0.0488 & 0.0231 & 0.1406 & 0.2802 & 0.0868 \\
\hline 0.4205 & 0.0165 & 0.2439 & 0.1155 & 0.2813 & 0.3735 & 0.2419 \\
\hline 0.2103 & 0.0231 & 0.0163 & 0.0192 & 0.0469 & 0.0078 & 0.0539 \\
\hline 0.2804 & 0.0192 & 0.0081 & 0.0144 & 0.2813 & 0.0467 & 0.1083 \\
\hline \multicolumn{7}{|c|}{ Normalized supermatrix of waterfront typologies on the indication of C3.1. Mixed-use development } \\
\hline Alt. 1. & Alt. 2. & Alt. 3. & Alt. 4. & Alt. 5. & Alt. 6. & Weightage (W) \\
\hline 0.0684 & 0.3934 & 0.1163 & 0.0337 & 0.0238 & 0.1311 & 0.1278 \\
\hline 0.0085 & 0.0492 & 0.1744 & 0.0404 & 0.0238 & 0.1967 & 0.0822 \\
\hline 0.2051 & 0.0984 & 0.3488 & 0.6061 & 0.1905 & 0.3279 & 0.2961 \\
\hline 0.4103 & 0.2459 & 0.1163 & 0.2020 & 0.2857 & 0.2623 & 0.2537 \\
\hline 0.2735 & 0.1967 & 0.1744 & 0.0673 & 0.0952 & 0.0164 & 0.1373 \\
\hline 0.0342 & 0.0164 & 0.0698 & 0.0505 & 0.3810 & 0.0656 & 0.1029 \\
\hline \multicolumn{7}{|c|}{ Normalized supermatrix of waterfront typologies on the indication of C3.2. Diversification } \\
\hline Alt. 1. & Alt. 2. & Alt. 3. & Alt. 4. & Alt. 5. & Alt. 6. & Weightage (W) \\
\hline 0.0303 & 0.0116 & 0.0132 & 0.0654 & 0.0076 & 0.0242 & 0.0254 \\
\hline 0.2424 & 0.0929 & 0.2112 & 0.1745 & 0.2672 & 0.0121 & 0.1667 \\
\hline 0.2424 & 0.0464 & 0.1056 & 0.0872 & 0.2672 & 0.3636 & 0.1854 \\
\hline 0.2424 & 0.2786 & 0.6337 & 0.5234 & 0.2672 & 0.5091 & 0.4091 \\
\hline 0.1515 & 0.0133 & 0.0151 & 0.0748 & 0.0382 & 0.0182 & 0.0518 \\
\hline 0.0909 & 0.5572 & 0.0211 & 0.0748 & 0.1527 & 0.0727 & 0.1616 \\
\hline \multicolumn{7}{|c|}{ Normalized supermatrix of waterfront typologies on the indication of C3.3. Employment opportunity } \\
\hline Alt. 1. & Alt. 2. & Alt. 3. & Alt. 4. & Alt. 5. & Alt. 6. & Weightage (W) \\
\hline 0.6154 & 0.8266 & 0.3019 & 0.4061 & 0.2759 & 0.5872 & 0.5022 \\
\hline 0.0769 & 0.1033 & 0.2642 & 0.3553 & 0.2414 & 0.2936 & 0.2224 \\
\hline 0.0769 & 0.0148 & 0.0377 & 0.0254 & 0.0690 & 0.0092 & 0.0388 \\
\hline 0.0769 & 0.0148 & 0.0755 & 0.0508 & 0.1724 & 0.0245 & 0.0691 \\
\hline 0.0769 & 0.0148 & 0.0189 & 0.0102 & 0.0345 & 0.0122 & 0.0279 \\
\hline 0.0769 & 0.0258 & 0.3019 & 0.1523 & 0.2069 & 0.0734 & 0.1395 \\
\hline
\end{tabular}

Note: Alt. 1. The Commercial Waterfront, Alt. 2. The Educational and Environmental Waterfront, Alt. 3. The Recreational Waterfront, Alt. 4. The Historic Waterfront, Alt. 5. The Residential Waterfront, Alt. 6. The working and Transportation Waterfront.

\section{References}

1. Breen, A.; Rigby, D. The New Waterfront: A Worldwide Urban Success Story; McGraw-Hill: New York, NY, USA, 1996.

2. Wong, T.C. Revitalising Singapore's Central City through Gentrification: The Role of Waterfront Housing. Urban Policy Res. 1996, 24, 181-199. [CrossRef]

3. Ali, S.M.; Nawawi, A.H. The Social Impact of Urban Waterfront Landscapes: Malaysian Perspectives. In Proceedings of the 14th International Conference on Urban Planning, Regional Development and Information Society, Sitges, Spain, 22-25 April 2009.

4. Romero, V.P.; Maffei, L.; Brambilla, G.; Ciaburro, G. Modelling the soundscape quality of urban waterfronts by artificial neural networks. Appl. Acoust. 2016, 111, 121-128. [CrossRef]

5. Shafaghat, A.; Manteghi, G.; Keyvanfar, A.; Bin Lamit, H.; Saito, K.; Ossen, D.R. Street Geometry Factors Influence Urban Microclimate in Tropical Coastal Cities: A Review. Environ. Clim. Technol. 2016, 17, 61-75. [CrossRef]

6. Shafaghat, A.; Keyvanfar, A.; Manteghi, G.; Lamit, H.B. Environmental-conscious factors affecting street microclimate and individuals' respiratory health in tropical coastal cities. Sustain. Cities Soc. 2016, 21, 35-50. [CrossRef] 
7. Sairinen, R.; Kumpulainen, S. Assessing social impacts in urban waterfront regeneration. Environ. Impact Assess. Rev. 2006, 26, 120-135. [CrossRef]

8. Da, T.; Xu, Y. Evaluation on connectivity of urban waterfront redevelopment under hesitant fuzzy linguistic environment. Ocean Coast. Manag. 2016, 132, 101-110. [CrossRef]

9. Lifang, Q.; Yichuan, Z.; Wei, C. Evaluation of urban river landscape design rationality based on AHP. Water Sci. Eng. 2008, 1, 75-81.

10. Rössler, M. World heritage cultural landscapes: A UNESCO flagship programme 1992-2006. Landsc. Res. 2006, 31, 333-353. [CrossRef]

11. Stewart, E.J.; Hayward, B.M.; Devlin, P.J.; Kirby, V.G. The "place" of interpretation: A new approach to the evaluation of interpretation. Tour. Manag. 1998, 19, 257-266. [CrossRef]

12. Oakley, $\mathrm{S}$. The role of urban governance in re-constructing place, economic function and social relations in urban waterfront regeneration: The case of Port Adelaide, South Australia. Space Polity 2007, 11, 279-295. [CrossRef]

13. Zhai, G.; Suzuki, T. Evaluating economic value of coastal waterfront in Tokyo Bay, Japan with willingnessto-accept measure. Water Resour. Manag. 2009, 23, 633-645. [CrossRef]

14. KoGirard, L.F.; Kourtit, K.; Nijkamp, P. Waterfront Areas as Hotspots of Sustainable and Creative Development of Cities. Sustainability 2014, 6, 4580-4586. [CrossRef]

15. Hoyle, B. Lamu: Waterfront revitalization in an East African port-city. Cities 2001, 18, 297-313. [CrossRef]

16. Hagerman, C. Shaping neighborhoods and nature: Urban political ecologies of urban waterfront transformations in Portland, Oregon. Cities 2007, 24, 285-297. [CrossRef]

17. López-Bonilla, J.; López-Bonilla, L.; Sanz-Altamira, B. Designated Public Festivals of Interest to Tourists. Eur. Plan. Stud. 2010, 18, 435-447. [CrossRef]

18. De Rosa, F.; Di Palma, M. Historic urban landscape approach and port cities regeneration: Naples between identity and outlook. Sustainability 2013, 5, 4268-4287. [CrossRef]

19. Kostopoulou, S. On the revitalized waterfront: Creative milieu for creative tourism. Sustainability 2013, 5, 4578-4593. [CrossRef]

20. Cheung, D.M.W.; Tang, B.S. Social order, leisure, or tourist attraction? The changing planning missions for waterfront space in Hong Kong. Habitat Int. 2015, 47, 231-240. [CrossRef]

21. Acosta, M.C. Reclaiming the waterfront through urban design guidelines: Case study of the Chicago River urban design guidelines. In Proceedings of the Seventh International Conference on Making Cities Livable, Carmel, CA, USA, 17-21 March 1990.

22. Sykora, L. Commercial property development in Budapest, Prague and Warsaw. In Social Change and Urban Restructuring in Central Europe; Enyedi, G., Ed.; Akademiai Kiado: Budapest, Hungary, 1990; pp. 109-136.

23. Vallega, A. Urban waterfront facing integrated coastal management. Ocean Coast. Manag. 2001, 44, 379-410. [CrossRef]

24. Edgell, D.L.; Allen, D.M.; Smith, G.; Swanson, J.R. Tourism as a commercial and economic activity. J. Tour. Policy Plan. 2008. [CrossRef]

25. Doratli, N.; Hoskara, S.O.; Fasli, M. An analytical methodology for revitalization strategies in historic urban quarters: A case study of the Walled City of Nicosia, North Cyprus. Cities 2004, 21, 329-348. [CrossRef]

26. Gordon, D.L. Implementing urban waterfront redevelopment in an historic context: A case study of the The Boston Naval Shipyard. Ocean Coast. Manag. 1999, 42, 909-931. [CrossRef]

27. Craigh-Smith, S.J. The importance and problems of city waterside regions. In Recreation and Tourism as a Catalyst for Urban Waterfront Redevelopment, an International Survey; Craigh-Smith, S.J., Fagence, M., Eds.; Praeger: London, UK, 1995; pp. 1-14.

28. Krausse, G.H. Tourism and waterfront renewal: Assessing residential perception in Newport, Rhode Island, USA. Ocean Coast. Manag. 1995, 26, 179-203. [CrossRef]

29. Doucet, B.; Van Kempen, R.; Van Weesep, J. Resident perceptions of flagship waterfront regeneration: The case of the Kop van Zuid in Rotterdam. Tijdschrift voor Economische en Sociale Geografie 2011, 102, 125-145. [CrossRef]

30. Airas, A.; Hall, P.V.; Stern, P. Asserting historical "distinctiveness" in industrial waterfront transformation. Cities 2015, 44, 86-93. [CrossRef]

31. Cuesta, R.; Moughtin, C.; Sarris, C.; Signoretta, P. Urban Design: Method and Techniques; Butterworth Architectural: Oxford, UK, 1990. 
32. Basheer, I.A.; Hajmeer, M. Artificial neural networks: Fundamentals, computing, design and application. J. Microbiol. Methods 2000, 43, 3-31. [CrossRef]

33. Yamashita, S. Perception and evaluation of water in landscape: Use of Photo-Projective method to compare child and adult residents' perceptions of a Japanese river environment. Landsc. Urban Plan. 2002, 62, 3-17. [CrossRef]

34. Cai, S.H.; Hu, X. Concept of river health and index system for its evaluation. Adv. Sci. Technol. Water Resour. 2008, 28, 23-26.

35. Chatterjee, K.; Bandyopadhyay, A.; Ghosh, A.; Kar, S. Assessment of environmental factors causing wetland degradation, using Fuzzy Analytic Network Process: A case study on Keoladeo National Park, India. Ecol. Model. 2015, 316, 1-13. [CrossRef]

36. Zhang, R.; Zhang, X.; Yang, J.; Yuan, H. Wetland ecosystem stability evaluation by using Analytical Hierarchy Process (AHP) approach in Yinchuan Plain, China. Math. Comput. Model. 2013, 57, 366-374. [CrossRef]

37. Saaty, T.L. Axiomatic foundation of the analytic hierarchy process. Manag. Sci. 1986, 32, 841-855. [CrossRef]

38. Velasquez, M.; Hester, P.T. An analysis of multi-criteria decision-making methods. Int. J. Oper. Res. 2013, 10, 56-66.

39. Saaty, T.L.; Vargas, L.G. How to make a decision. In Models, Methods, Concepts \& Applications of the Analytic Hierarchy Process; Springer: New York, NY, USA, 2012; pp. 1-21.

40. Saaty, T.L. How to make a decision: The analytic hierarchy process. Interfaces 1994, 24, 19-43. [CrossRef]

41. Shafaghat, A.; Ghasemi, M.M.; Keyvanfar, A.; Lamit, H.; Ferwati, M.S. Sustainable riverscape preservation strategy framework using goal-oriented method: Case of historical heritage cities in Malaysia. Int. J. Sustain. Built Environ. 2017, 6, 143-159. [CrossRef]

42. Lamit, H.; Shafaghat, A.; Majid, M.Z.; Keyvanfar, A.; Ahmad, M.H.B.; Malik, T.A. Grounded group decision-making (GGDM) model. Adv. Sci. Lett. 2013, 19, 3077-3080. [CrossRef]

43. Wolf, F.M.; Shea, J.A.; Albanese, M.A. Toward setting a research agenda for systematic reviews of evidence of the effects of medical education. Teach. Learn. Med. 2001, 13, 53-60. [CrossRef]

44. Giovinazzi, O.; Moretti, M. Port Cities and Urban Waterfront: Transformations and Opportunities. Tema J. Land Use Mobil. Environ. 2010. [CrossRef]

45. Mah, A. Port Cities and Global Legacies: Urban Identity, Waterfront Work and Radicalism; Springer: New York, NY, USA, 2014.

46. Arnott, R.; Small, K. The economics of traffic congestion. Am. Sci. 1994, 82, 446-455.

47. Ebbe, K. Infrastructure and Heritage Conservation: Opportunities for Urban Revitilization and Economic Development. Directions in Urban Development. 2009. Available online: http:/ / siteresources.worldbank. org/INTURBANDEVELOPMENT/Resources /336387-1226422021646/Directions3.pdf?resourceurlname= Directions3.pdf (accessed on 8 November 2017).

48. Malpas, J. New media, cultural heritage and the sense of place: Mapping the conceptual ground. Int. J. Heritage Stud. 2008, 14, 197-209. [CrossRef]

49. Hartig, J.H.; Wallace, M.C. Creating World-Class Gathering Places for People and Wildlife along the Detroit Riverfront, Michigan, USA. Sustainability 2015, 7, 15073-15098. [CrossRef]

50. Hartig, J.H.; Bennion, D. Historical Loss and Current Rehabilitation of Shoreline Habitat along an Urban-Industrial River-Detroit River, Michigan, USA. Sustainability 2017, 9, 828. [CrossRef]

51. Nelson, A. Travel Time to Major Cities: A Global Map of Accessibility; Global Environment Monitoring Unit-Joint Research Centre of the European Commission: Ispra, Italy, 2008.

52. Ahmad, S.M.; Choudhury, D. Pseudo-dynamic approach of seismic design for waterfront reinforced soil-wall. Geotext. Geomembr. 2008, 26, 291-301. [CrossRef]

53. Balsas, C. Downtown resilience: A review of recent (re)developments in Tempe, Arizona. Cities 2012, 36, 158-169. [CrossRef]

54. Lamit, H.B.; Shafaghat, A.; Majid, M.Z.; Keyvanfar, A.; Ahmad, M.A.; Yadollahi, M. Application of the Path Walkability Index (Pawdex) Model: A Case Study of Retail Walking Pattern Recognition in Taman University Skudai, Johor, Malaysia. Adv. Sci. Lett. 2013, 19, 3021-3024. [CrossRef]

55. Lamit, H.B.; Shafaghat, A.; Majid, M.Z.; Keyvanfar, A.; Ahmad, M.H.B.; Malik, T.A. The Path Walkability Index (PAWDEX) Model: To Measure Built Environment Variables Influencing Residents' Walking Behavior. Adv. Sci. Lett. 2013, 19, 3017-3020. [CrossRef] 
56. Szili, G.; Rofe, M.W. Greening Port Misery: Marketing the green face of waterfront redevelopment in Port Adelaide, South Australia. Urban Policy Res. 2007, 25, 363-384. [CrossRef]

57. Alonso, J.A.; Lamata, M.T. Consistency in the analytic hierarchy process: A new approach. Int. J. Uncertain. Fuzziness Knowl.-Based Syst. 2006, 14, 445-459. [CrossRef]

58. Merriam, S.B. Qualitative Research and Case Study Applications in Education; Jossey-Bass: San Francisco, CA, USA, 1998.

59. Saunders, M.N. Choosing research participants. In The Practice of Qualitative Organizational Research: Core Methods and Current Challenges; Sage: London, UK, 2012; pp. 35-52.

60. Patton, M.Q. Qualitative Research E Evaluation Methods; SAGE Publications, Inc.: London, UK, 2001; p. 688.

61. Fishburn, P.C. Additive Utilities with Incomplete Product Set: Applications to Priorities and Assignments. Oper. Res. 1967, 15, 537-542. [CrossRef]

62. Marler, R.T.; Arora, J.S. The weighted-sum method for multi-objective optimization: New insights. Struct. Multidiscip. Optim. 2009, 41, 853-862. [CrossRef]

63. Rodwell, D. Planning systems: Do they fit the current needs of historic port cities? In On the Waterfront: Culture, Heritage and Regeneration of Port Cities; BT Convention Centre, Kings Waterfront: Liverpool, UK, 2008.

64. Simon, D. Urban environments: Issues on the peri-urban fringe. Annu. Rev. Environ. Resour. 2008, 33, 167-185. [CrossRef]

65. Al-hagla, K.S. Sustainable urban development in historical areas using the tourist trail approach: A case study of the Cultural Heritage and Urban Development (CHUD) project in Saida, Lebanon. Cities 2010, 27, 234-248. [CrossRef]

66. Osman, K.A.; Farahat, B.I. The conservation of the waterfront of Saida: A model for tourism and culture-led revitalization in valuable areas. HBRC J. 2017. [CrossRef]

67. Bredvold, R.; Skålén, P. Lifestyle entrepreneurs and their identity construction: A study of the tourism industry. Tour. Manag. 2016, 56, 96-105. [CrossRef]

68. Nyseth, T.; Sognnæs, J. Preservation of old towns in Norway: Heritage discourses, community processes and the new cultural economy. Cities 2012, 31, 69-75. [CrossRef]

69. Portman, M.E.; Jin, D.; Thunberg, E. Waterfront land use change and marine resource conditions: The case of New Bedford and Fairhaven, Massachusetts. Ecol. Econ. 2009, 68, 2354-2362. [CrossRef]

70. Pendlebury, J.; Short, M.; While, A. Urban World Heritage Sites and the problem of authenticity. Cities 2009, 26, 349-358. [CrossRef]

71. Salamone, F.A. Authenticity in tourism: The San Angel inns. Ann. Tour. Res. 1997, 24, 305-321. [CrossRef]

72. Waitt, G. Consuming heritage: Perceived historical authenticity. Ann. Tour. Res. 2000, 27, 835-862. [CrossRef] 